\title{
Glacial state of the global carbon cycle: time-slice simulations for the last glacial maximum with an Earth-system model
}

\author{
Takasumi Kurahashi-Nakamura ${ }^{1}$, André Paul ${ }^{1}$, Ute Merkel ${ }^{1}$, and Michael Schulz ${ }^{1}$ \\ ${ }^{1}$ MARUM - Center for Marine Environmental Sciences and Faculty of Geosciences, University of Bremen, Bremen, Germany \\ Correspondence: Takasumi Kurahashi-Nakamura (tkurahashi@marum.de)
}

\begin{abstract}
Three time-slice carbon-cycle simulations for the last glacial maximum (LGM) constrained by the $\mathrm{CO}_{2}$ concentration in the atmosphere and the amount of carbon stored in the deep ocean were carried out with a fully-coupled comprehensive climate model CESM1.2 (the Community Earth System Model version 1.2). Although the three modeled LGM ocean states had remarkably different physical features, all of them were compatible with the pre-industrial (PI) state in terms of the global ocean carbon inventory considering the presumed transfers of carbon among the various reservoirs during the evolution from the LGM to PI. The increase in the total alkalinity required to simulate ocean states that is deemed appropriate for the LGM was quantitatively in line with the scenario of post-glacial shallow water deposition of calcium carbonate, suggesting that the reconstructed estimates of the glacial deep-ocean carbon inventory and those of the amount of carbonate deposition on shelves are in agreement with each other. On the other hand, comparisons between the simulated distributions of paleoceanographic tracers and corresponding reconstructions clearly distinguished the different geometry of ocean-circulation cells and favored a shallower Atlantic meridional overturning circulation (AMOC) for the LGM compared to PI.
\end{abstract}

\section{Introduction}

The transition of the global climate from the LGM to the modern era is characterized by a remarkable increase of atmospheric $\mathrm{CO}_{2}$ concentration ( $\mathrm{CO}_{2}$; e.g., Petit et al., 1999; Augustin et al., 2004). Although quite a few hypotheses were proposed to explain this fact by a single process (Archer et al., 2000), it is now widely recognized that the whole $p \mathrm{CO}_{2}$ change can only be explained by a combination of processes that act in different components of the climate system at different times during the course of the last deglaciation (e.g., Ridgwell et al., 2003; Brovkin et al., 2007, 2012; Ganopolski and Brovkin, 2017). Thorough understanding of the underlying mechanisms would benefit from a time-dependent or transient simulation with a fully-coupled comprehensive climate model including the global carbon cycle. Such a simulation is not only indispensable for a better understanding of past climate dynamics but also for testing and evaluating climate models to be employed in future climate projections. 
Transient simulations that start from the LGM pose a serious challenge regarding the initial model state. Ideally, they should start from a "true" LGM state that results from the entire history of the global carbon cycle since (at least) the penultimate interglacial period. However, because computational cost for such long-term simulations with a comprehensive climate model is prohibitive, a more practical way is to carry out time-slice simulations for the LGM that are subject to reconstructed boundary conditions such as greenhouse-gas concentrations and the orbital elements.

Given all of our current knowledge, it is still difficult to uniquely define the physical and biogeochemical ocean state during the LGM, let alone the entire climate system. As to the physical state, recent numerical-model-based studies (e.g., Menviel et al., 2017; Kurahashi-Nakamura et al., 2017; Gu et al., 2020; Muglia and Schmittner, 2021) tackled the issue of the LGM ocean state by utilizing carbon isotopes and other biogeochemical tracers as constraints. Consensus seems to be in reach regarding the water-mass geometry but not for the circulation intensity.

From a biogeochemical point of view, the total inventory of carbon and total alkalinity in the ocean is an important factor because it is expected that both would have a large influence on $p \mathrm{CO}_{2}$. On the one hand, the inventory of dissolved inorganic carbon (DIC) in the deep ocean has been estimated based on an empirical linear relationship between the ${ }^{14} \mathrm{C}$ ventilation age and modern concentrations of DIC below a depth of $2000 \mathrm{~m}$, suggesting that the average DIC concentration in these depths was higher during the LGM by $85-115 \mu \mathrm{mol} / \mathrm{kg}$ (Sarnthein et al., 2013) or $82 \mu \mathrm{mol} / \mathrm{kg}$ (Skinner et al., 2015) as compared to the modern. On the other hand, a substantial amount of alkalinity is considered to have been removed from the LGM ocean by the post-glacial shallow water deposition of $\mathrm{CaCO}_{3}$ as proposed in the "coral reef hypothesis" (e.g., Berger, 1982; Opdyke and Walker, 1992), and it is estimated that the process would account for the removal of total alkalinity as much as 0.44-3.6 $\times 10^{17}$ eq (Milliman, 1993; Opdyke, 2000; Ridgwell et al., 2003; Vecsei and Berger, 2004; Husson et al., 2018; Köhler and Munhoven, 2020).

The main purpose of this study is to carry out fully-coupled LGM time-slice simulations including the global carbon cycle. In addition to following the established PMIP4 protocol regarding LGM boundary conditions (Kageyama et al., 2017), we adjusted the total inventories of DIC and total alkalinity in the ocean to satisfy two important constraints in terms of the size of carbon reservoirs during the LGM: $p \mathrm{CO}_{2}$ and reconstructed mean DIC concentration in the deep ocean. We evaluate the LGM marine carbon cycle from the perspective of the specific change in the $\mathrm{pH}$ of seawater that is compatible with the low$p \mathrm{CO}_{2}$ atmosphere. The carbonate ion concentration $\left[\mathrm{CO}_{3}^{2-}\right]$ in the deep ocean is tightly linked to processes that affect carbon reorganization in the ocean and thus is a valuable tracer for investigating the global carbon cycle (e.g., Yu et al., 2014). The simulated $\left[\mathrm{CO}_{3}^{2-}\right]$ and the mass accumulation rate (MAR) of $\mathrm{CaCO}_{3}$ at the ocean floor are both compared to reconstructions. We also discuss the compatibility between the modeled LGM and modern states in terms of the carbon and alkalinity budget. That is to say, we examine the likelihood that we can reconcile the total inventory of DIC and alkalinity of the modeled LGM states with the modern counterparts taking into account the changes of the sizes of several reservoirs through the transition from the LGM to PI. 
https://doi.org/10.5194/cp-2022-8

Preprint. Discussion started: 14 February 2022

(c) Author(s) 2022. CC BY 4.0 License.

(c) (i)

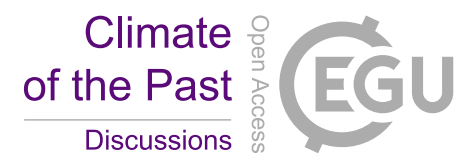

\section{Methods}

\subsection{Models}

We used the Community Earth System Model (CESM; Hurrell et al., 2013) version 1.2, which is an atmosphere-ocean-land coupled comprehensive Earth-system model. The ocean component, the Parallel Ocean Program version 2 (POP2), was config-

5 ured to include the Biogeochemical Elemental Cycling model (BEC; Moore et al., 2004, 2013; Lindsay et al., 2014). The BEC included a nutrient-phytoplankton-zooplankton-detritus (NPZD) marine ecosystem model and handled sinking processes of biological particles. For the sinking of particulate organic matter (POM), the "ballast effect" was taken into account based on Armstrong et al. (2002). The ocean component was extended by the carbon-isotope package developed by Jahn et al. (2015) so that we were able to explicitly simulate the carbon-isotope composition of seawater. The land component (the Community Land Model; CLM4.0) included prognostic treatment of the terrestrial carbon and nitrogen cycles to calculate the reservoir size of land carbon. A low-resolution setting of CESM was used in this study to reduce the computational cost (Shields et al., 2012); that is to say, the ocean component had a nominal $3^{\circ}$ irregular horizontal grid with 60 vertical levels, while the atmosphere component, Community Atmosphere Model version 4 (CAM4), had a T31 spectral dynamical core (horizontal resolution of $3.75^{\circ}$ ) with 26 vertical levels.

In this study, the size of each carbon reservoir including the atmospheric $p \mathrm{CO}_{2}$ is calculated by the prognostic carbon cycle model. However, we switched off the feedback from the carbon cycle to the climate system by prescribing a constant $p \mathrm{CO}_{2}$ that determined the radiative forcing. For a similar reason, we treated the marine biogeochemical system as being "closed" to exclude the drift of the total inventory from prescribed amounts, that is, there were no fluxes of biogeochemical matter through the top and bottom boundaries of the ocean domain except for the air-sea gas exchange. The particulate matter that reached the ocean floor was assumed to be dissolved in the bottom layer. To enhance the numerical stability, we replaced the original pH solver in POP2 with SolveSAPHE (Solver Suite for Alkalinity-pH Equations) developed by Munhoven (2013). We took account of the alkalinity that arises from the dissociation of the solvent water itself in addition to the carbonate and borate alkalinity, which provided a sufficiently accurate solution (Munhoven, 2013).

For diagnostic purposes, we adopted the Model of Early Diagenesis in the Upper Sediment of Adjustable complexity (MEDUSA(v.2); Munhoven, 2020) to explicitly calculate the preservation or dissolution of $\mathrm{CaCO}_{3}$ at the ocean floor that corresponded to each of our CESM simulations. MEDUSA is a one-dimensional advection-diffusion-reaction model that, in its original setup, describes the early diagenetic processes involving carbonates and organic matter (OM) in the surface sediment of $10 \mathrm{~cm}$ thickness as function of time. The configuration of MEDUSA was the same as in our previous application (Kurahashi-Nakamura et al., 2020) except for diffusive boundary layers (DBL) to better represent the solute fluxes across the water-sediment boundaries (Munhoven, 2020) in this study.

\subsection{Experiments and analyses}

We performed four main time-slice experiments: one control experiment that corresponds to the PI reference period, and three experiments with the LGM as a target (Table 1). For the PI run (expPI) we followed the DECK (Diagnostic, Evaluation and 
https://doi.org/10.5194/cp-2022-8

Preprint. Discussion started: 14 February 2022

(c) Author(s) 2022. CC BY 4.0 License.

(c) (i)

Characterization of Klima) PI control protocol (Eyring et al., 2016) for the physical forcing to CESM. The control experiment was initialized from the final state of the spin-up run of Kurahashi-Nakamura et al. (2020) and run for 2500 model years. For the model parameters, we followed the default settings of CESM1.2.

For the LGM runs, we followed the experimental design established by the Paleoclimate Modelling Intercomparison Project

5 Phase 4 (PMIP4; Kageyama et al., 2017). We set the radiative and orbital forcing parameters as specified in this protocol, and adjusted the ice sheet configuration based on the ICE-6G-C reconstruction (Argus et al., 2014; Peltier et al., 2015). The dust and aerosols forcings of the atmosphere and marine biogeochemistry are based on Albani et al. (2014). The mean salinity and nutrient concentrations of the ocean were modified according to the change in ocean volume (Kageyama et al., 2017).

For the baseline LGM experiment (expLGM), following a separate physical spin-up without the marine biogeochemistry, we carried out a 2500-year fully-coupled carbon-cycle run. We also conducted two sensitivity experiments with the same length for the LGM (expLGMws and expLGMss) with additional freshwater forcing to examine the dependency of the biogeochemical states on the physical ocean state (Fig. 1). For the first sensitivity experiment (expLGMws), $0.1 \mathrm{~Sv}$ additional freshwater in total was uniformly added to the so-called "Ruddiman belt" in the high-latitude Northern Atlantic Ocean. The southern boundary of the "hosing" region was defined by $50 \mathrm{~N}^{\circ}$, and the others by suitable CESM1.2 region masks. For the second sensitivity experiment (expLGMss), we subtracted $0.1 \mathrm{~Sv}$ from the same high-latitude region in the Northern Atlantic Ocean and $0.25 \mathrm{~Sv}$ in total from the Weddell Sea and Ross Sea regions. The primary motivation for the additional freshwater forcing was to prepare different physical ocean states as in previous studies (e.g., Gu et al., 2020; Muglia and Schmittner, 2021). Implicitly they take into account the uncertainty in the glacial freshwater budget in high latitudes due to ice-sheet calving and iceberg transport and melting processes (Merino et al., 2016) that were not explicitly modelled in our framework. The total sea-water volume and hence the global-mean concentrations of tracers were conserved by adding uniform compensating fluxes of the opposite sign over the rest of the global ocean.

The DIC inventory of each LGM simulation (Table 1) was set based on an independent proxy-based estimate of the increase in the mean DIC concentration of the deep ocean as compared to the PI ocean state by Sarnthein et al. (2013). The individual amount of the additional DIC for each LGM simulation was determined through preceding preparatory simulations for a "first guess". To initialize those runs, we increased the global mean DIC concentration homogeneously by $100 \mathrm{mmol} / \mathrm{m}^{3}$ compared to the PI amount (Table 2). Depending on the respective LGM simulations, we also added $75-100 \mathrm{meq} / \mathrm{m}^{3}$ of total alkalinity on top of the ocean-volume effect to tune the model so that a $p \mathrm{CO}_{2}$ level between $180 \mathrm{ppm}$ and $190 \mathrm{ppm}$ was reached. After a 1000-yr model integration for each simulation, we calculated the resulting mean DIC anomalies in the ocean deeper than $2000 \mathrm{~m}$ in accordance with Sarnthein et al. (2013). To set the initial DIC inventory for the main LGM simulations, we took the difference between each of the posterior DIC anomalies of the preparatory runs and the observation-based estimate, and adjusted the first guess by adding the difference. Thereby we obtained "second-guess" values that were used to initialize the respective main LGM runs (Table 1), so that we were able to achieve the DIC anomalies in the deep ocean in better accordance with the estimate by Sarnthein et al. (2013). For the main LGM runs, we newly adjusted the total alkalinity (Table 1). The increment was chosen similarly such that the model predicted an atmospheric $p \mathrm{CO}_{2}$ level of approximately 190 ppm based on ice-core-based records (Bereiter et al., 2015; Köhler et al., 2017). The initial $\delta^{13} \mathrm{C}$ of DIC was uniformly zero, and we assumed 
https://doi.org/10.5194/cp-2022-8

Preprint. Discussion started: 14 February 2022

(c) Author(s) 2022. CC BY 4.0 License.

\section{(c) (i)}

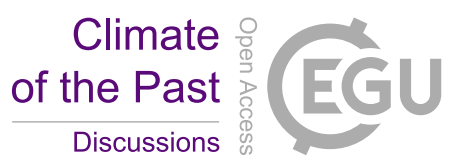

the $\delta^{13} \mathrm{C}$ value of the atmosphere during the LGM to be $-6.46 \%$ (Schmitt et al., 2012). We analyzed time-averaged model states based on the last 50 years of the respective experiments unless otherwise stated.

For each experiment, we also diagnosed and analyzed upper-sediment properties with regard to $\mathrm{CaCO}_{3}$ by running MEDUSA separately as a stand-alone model, taking the appropriate boundary conditions from the corresponding CESM state. For this purpose and considering that the carbonate chemistry in the upper sediment is significantly pressure-dependent, the CESM output was downscaled to a $1^{\circ} \times 1^{\circ}$ horizontal grid to utilize higher-resolution ocean-floor bathymetry (Argus et al., 2014; Peltier et al., 2015). In this way, MEDUSA was forced by a more accurate local water depth that allowed for an improved representation of the carbonate chemistry. However, the regions where the high-resolution bathymetry is deeper than the bottom depths of POP2 are excluded from the analyses to avoid the uncertainty due to the extrapolation of CESM output in the depth direction.

\section{Results}

\subsection{Physical ocean states}

The different forcing factors and boundary conditions yielded four very distinct physical ocean states. As expected, there were noticeable differences in the global ocean circulation and water-mass distributions. The standard LGM experiment (expLGM) had a stronger Atlantic meridional ocean circulation (AMOC) with a similar depth structure compared to that of the preindustrial run (expPI) (Fig. 2). The experiments with the additional freshwater forcing resulted in noticeably shallower AMOCs, which shoaled by $500-1000 \mathrm{~m}$ in terms of the position of the zero-flux that separates the upper and lower circulations cells (Fig. 2), which can be associated with the North Atlantic Deep Water (NADW) and Antarctic Bottom Water (AABW) masses. On the other hand, the maximum strength of the upper circulation in expLGMss was stronger than in expPI, while that for expLGMws was weaker. In short, expLGMss had a "stronger but shallower" AMOC compared to PI, while expLGMws had a "weaker and shallower" AMOC. Both the experiments showed stronger bottom circulations than expPI or expLGM.

The differences in the annually-averaged global-mean sea surface temperature (SST) between the respective LGM experiment and expPI were $-2.6 \mathrm{~K}$ (expLGM), $-2.7 \mathrm{~K}$ (expLGMss), and $-2.0 \mathrm{~K}$ (expLGMws). Those values were within the range of various estimates of the mean SST anomaly for the LGM (Annan and Hargreaves, 2013; Kurahashi-Nakamura et al., 2017;

25 Tierney et al., 2020; Paul et al., 2021) implying that the solubility of $\mathrm{CO}_{2}$ in the LGM runs, hence the carbon distribution between the atmosphere and the ocean, was reasonably modeled in general. In all the LGM runs, the vertical gradient of salinity is larger in most regions compared to expPI (i.e. comparatively more saline in the very deep ocean apart from the uniform volume effect), corresponding to more stratified ocean states (Fig. 3).

\subsection{Carbon reservoirs}

30 The $p \mathrm{CO}_{2}$ predicted by the carbon cycle module of the model was in a quasi-steady state during at least the last 1000 years of all the experiments. In expPI, we obtained $276 \mathrm{ppm}$ (Table 3). This value agreed well with the prescribed radiative $p \mathrm{CO}_{2}$ that 
https://doi.org/10.5194/cp-2022-8

Preprint. Discussion started: 14 February 2022

(c) Author(s) 2022. CC BY 4.0 License.

\section{(c) (i)}

was used to force the model climate $(280 \mathrm{ppm})$, demonstrating an excellent ability of the model to predict a $p \mathrm{CO}_{2}$ consistent with a given climate state. All the LGM runs reached a $p \mathrm{CO}_{2}$ in the range between $180 \mathrm{ppm}$ and $190 \mathrm{ppm}$ as aimed for, which was approximately $90 \mathrm{ppm}$ lower than in expPI, in good agreement with the $p \mathrm{CO}_{2}$ difference obtained from ice cores (Bereiter et al., 2015; Köhler et al., 2017).

The posterior anomaly of the mean DIC concentration in the deep ocean ( $>2000 \mathrm{~m})$ as the result of the 2500-year model integration was in the range between $102 \mathrm{mmol} / \mathrm{m}^{3}$ and $116 \mathrm{mmol} / \mathrm{m}^{3}$. The "second guess" reasonably captured the target based on the estimate by Sarnthein et al. (2013).

The simulated sizes of the land carbon storage were similar among the three LGM runs and ranged between $1.44 \times 10^{3} \mathrm{GtC}$ and $1.49 \times 10^{3} \mathrm{GtC}$. They were $340 \mathrm{GtC}$ to $390 \mathrm{GtC}$ smaller than in expPI (Table 3).

\subsection{Tracer fields in the ocean}

The vertical structure found in the distributions of biogeochemical tracers relfected the characteristics of each LGM experiment. The two experiments with a shallower AMOC (expLGMss and expLGMws) on the whole showed a similar structure in the meridional sections of the Atlantic Ocean, while those for expLGM revealed markedly different features (Figs. 3 and 4).

On the one hand, an important property of the tracer distributions is the vertical gradient or deep-to-shallow contrast. In expLGMss and expLGMws, $\delta^{13} \mathrm{C}_{\mathrm{DIC}}$ is higher in the upper ocean by $\sim 1 \%$ compared to those in expPI, and lower in the deeper ocean to a similar degree (Fig. 3d-f). This contrast was significantly smaller in expLGM. In particular, the negative anomaly in the bottom water in the North Atlantic was only -0.1 to $-0.2 \%$. Such a notable difference in the vertical structure was also observed in the distributions of dissolved phosphate. In expLGMss and expLGMws, the anomaly in phosphate concentration reached more than $1 \mathrm{mmol} / \mathrm{m}^{3}$ in the lower half of the depth range, while it was negligible for the expLGM counterpart (Fig. 3gi). This difference was in accordance with the distribution of the apparent $\mathrm{O}_{2}$ utilization (AOU) (Fig. 4a-c), suggesting that the strong positive anomalies of phosphate concentration in expLGMss and expLGMws were largely caused by an increase in remineralized phosphate. The export production was similar in all the experiments (Table 3), and therefore, the increased phosphate levels implied a more stagnant deep water causing longer-lasting storage of remineralized organic matter, or a more efficient soft-tissue pump. The ideal age tracer also supported this interpretation. In both expLGMss and expLGMws, the shallower NADW resulted in less-ventilated older deep water (>2000 m) compared to expLGM (Fig. 4d-f).

Those features are also in line with the distribution of the carbonate ion concentration $\left[\mathrm{CO}_{3}^{2-}\right]$ (Fig. 4g-i). The increased storage of remineralized carbon in the deep water for expLGMss and expLGMws resulted in lower $\left[\mathrm{CO}_{3}^{2-}\right]$ accompanied by a lower $\mathrm{pH}$ of seawater as compared to those in expLGM, and then led to a larger vertical gradient of the concentration. This biological pump effect was superposed onto the general rise of $\left[\mathrm{CO}_{3}^{2-}\right]$ caused by the globally increased alkalinity, so that $\left[\mathrm{CO}_{3}^{2-}\right]$ was higher in all the LGM experiments than in expPI on average.

On the other hand, the horizontal distributions of indicators of marine biological production clearly distinguished expLGMws from expLGMss. In expLGMws, the comparatively inactive deep convection in the northern North Atlantic caused a lower supply of macronutrients to the surface water, which resulted in a smaller amount of carbon export to the deep ocean (Fig. 5c) and a smaller nitrate concentration (Fig. 5f) in that region. In the other two LGM experiments, on the contrary, the more 
https://doi.org/10.5194/cp-2022-8

Preprint. Discussion started: 14 February 2022

(c) Author(s) 2022. CC BY 4.0 License.

(c) (i)

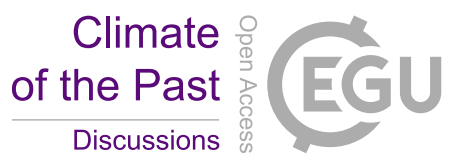

vigorous vertical mixing stimulated biological production leading to an increase in carbon export and less depleted nitrate concentrations. Another noteworthy feature common to all LGM experiments was the clear increase of carbon export in the so-called high-nutrient, low-chlorophyll (HNLC) regions: the Southern Ocean and the eastern equatorial Pacific, in particular. The increased atmospheric dust input in the LGM experiments boosted the biological production in those regions by iron

5 fertilization (Fig. 5a-c), which was accompanied by more efficient consumption of macro nutrients resulting in significantly smaller concentrations of nitrate at the surface in those regions (Fig. 5d-f).

\section{4 $\mathrm{CaCO}_{3}$ in the upper sediments}

The spatial distributions of the $\mathrm{CaCO}_{3}$ weight fraction in the upper sediment simulated by MEDUSA did not show distinctive differences among the LGM experiments (not shown). A key proxy-based criterion to assess the model results is the fact that the weight fraction for the LGM is lower in the Atlantic Ocean and higher in the Pacific Ocean than for the PI (Catubig et al., 1998), and all of the three LGM simulations satisfied this requirement in spite of the diverse global ocean states.

However, a comparison of the mass accumulation rate (MAR) of $\mathrm{CaCO}_{3}$ in the North Atlantic Ocean among the LGM simulations revealed that expLGMws was different in one aspect from expLGM and expLGMss when compared to the data by Cartapanis et al. (2018) (Fig. 6). The reconstruction indicates a significantly lower MAR in the mid-latitude North Atlantic Ocean, which was only reproduced in expLGMws. The anomalies of the $\mathrm{CaCO}_{3} \mathrm{MAR}$ in that region were controlled by the supply of $\mathrm{CaCO}_{3}$ to the sediments rather than its preservation and reflected a direct influence of the different magnitude of vertical mixing by local deep convection in line with the results shown in Section 3.3. That is to say, the weaker vertical mixing in expLGMws caused a smaller supply of macronutrients to the surface, which leads to a lower export of $\mathrm{CaCO}_{3}$ in that region (Fig. 7).

\section{Discussion}

\subsection{Budget of the alkalinity and DIC inventories}

A prerequisite for an acceptable marine biogeochemical state for the LGM is that the total inventories of total alkalinity and DIC are compatible with the PI inventories. In other words, the differences in those ocean inventories between the two time periods need to be consistent with the changes in the inventories of the other reservoirs across the deglaciation. In the three LGM experiments of this study, $40 \mathrm{meq} / \mathrm{m}^{3}$ to $80 \mathrm{meq} / \mathrm{m}^{3}$ of alkalinity was added in addition to the increase due to the change of the seawater volume (Table 1). The excess of alkalinity corresponds to $0.5 \times 10^{17}$ eq to $1.0 \times 10^{17}$ eq in terms of the inventory in the ocean.

Assuming that those amounts of alkalinity were removed from the ocean by a net deposition of $\mathrm{CaCO}_{3}, 2.5 \times 10^{16}$ mol to $5.0 \times 10^{16} \mathrm{~mol}$ of $\mathrm{CaCO}_{3}$ needed to be transferred to a different reservoir to account for the alkalinity decrease. Estimated amounts of the post-glacial shallow water deposition of $\mathrm{CaCO}_{3}$ by coral reef buildup following the sea-level rise ranges from $2.2 \times 10^{16}$ to $18 \times 10^{16} \mathrm{~mol}$ (Milliman, 1993; Opdyke, 2000; Ridgwell et al., 2003; Vecsei and Berger, 2004; Husson et al., 
https://doi.org/10.5194/cp-2022-8

Preprint. Discussion started: 14 February 2022

(C) Author(s) 2022. CC BY 4.0 License.

\section{(c) (i)}

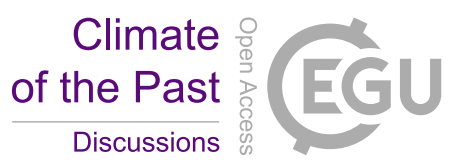

2018; Köhler and Munhoven, 2020), which would suggest that the extra alkalinity could be readily removed by that process.

That is also supported by another estimation for the modern inorganic carbon burial in shallow water environments given by Cartapanis et al. (2018).

Besides alkalinity, the compatibility with regard to the DIC inventory is examined as well. Out of the added $0.9 \times 10^{17}$ mol C 5 to $1.2 \times 10^{17} \mathrm{~mol} \mathrm{C}$, which corresponds to $72 \mathrm{mmol} / \mathrm{m}^{3}$ to $94 \mathrm{mmol} / \mathrm{m}^{3}, 2.5-5.0 \times 10^{16} \mathrm{~mol}$ was to be removed by the shallow water deposition of $\mathrm{CaCO}_{3}$. The rest $\left(4.0 \times 10^{16} \mathrm{~mol}\right.$ to $9.5 \times 10^{16} \mathrm{~mol}$, or $480 \mathrm{GtC}$ to $\left.1140 \mathrm{GtC}\right)$, therefore, needs to be removed by other processes. The most probable one is the growth of the atmospheric reservoir. The increase in $p \mathrm{CO}_{2}$ by 90 ppm between the LGM and PI corresponds to a $190 \mathrm{GtC}$ expansion in the size of this reservoir. Another promising candidate would be the terrestrial carbon reservoir. The modeled terrestrial reservoir in this study indicates a growth by $340 \mathrm{GtC}$ to $390 \mathrm{GtC}$. The sum of the changes in both the reservoirs is 530-580 GtC, which leaves $-100 \mathrm{GtC}$ to $610 \mathrm{GtC}$ (i.e. [480-580] to [1140-530]) to be explained by further processes.

A plausible process to fill the gap could be again the post-glacial shallow water deposition. An estimate of the modern deposition flux of organic carbon on shelves is 50-500 GtC/kyear (Cartapanis et al., 2018), which might suffice to remove the excess as long as it is a typical amount during a substantial portion of the Holocene, although there are no direct records of the organic-carbon deposition on continental margins over time (Cartapanis et al., 2018). Presumably, $\mathrm{CO}_{2}$ release through pyrite oxidation on exposed continental shelves during a glacial sea-level lowstand (Kölling et al., 2019) would add to the complexity of the change in carbon reservoirs across the deglaciation. It is expected that the sulfuric acid produced during pyrite oxidation is buffered with the dissolution of calcium carbonate minerals to lead to the release of $\mathrm{CO}_{2}$. The associated $\mathrm{CO}_{2}$ release rate is estimated to be between $12 \mathrm{GtC} / \mathrm{kyear}$ and $36 \mathrm{GtC} / \mathrm{kyear}$ if the acid is completely buffered by carbonate-mineral dissolution. The $\mathrm{CO}_{2}$ release triggered by the erosion and oxidation of pyrite that happened underground during the LGM might be delayed due to the transfer of $\mathrm{CO}_{2}$ to the surface. For the LGM, a model-based estimate of the cumulative $\mathrm{CO}_{2}$ release by buffering acids was $140 \mathrm{GtC}$ (Kölling et al., 2019). As an extreme case, even if all of the released $\mathrm{CO}_{2}$ reached the atmosphere during the deglaciation with a delay, that volume might be readily counteracted by the organic carbon deposition referred to above (50-500 GtC/kyear; Cartapanis et al., 2018). Another highly uncertain aspect is the relative change of the terrestrial-reservoir size. As compiled by Kemppinen et al. (2019), the estimates by previous studies of the growth of the terrestrial carbon inventory from LGM to PI span -500 to $1500 \mathrm{GtC}$, although the majority supports a (positive) growth toward PI. The residual DIC excess (i.e. 480-1140 GtC) that needs to be removed apart from the contribution of the $\mathrm{CaCO}_{3}$ deposition is in the range of these additional processes. To sum up, the removal of the whole excess of DIC is consistent with a combined contribution of the mechanisms mentioned above.

\subsection{Comparison with previous studies regarding the biogeochemical states}

Many past studies attempted to constrain the LGM ocean state by utilizing the distribution of the stable carbon isotope ratio $\delta^{13} \mathrm{C}_{\text {DIC }}$ (e.g., Tagliabue et al., 2009; Menviel et al., 2017; Kurahashi-Nakamura et al., 2017; Muglia et al., 2018; Gu et al., 2020; Muglia and Schmittner, 2021). It turned out that this tracer is useful in determining the spatial distribution of water masses but much less in terms of the strength of the AMOC. This study supports this conclusion. The noticeable negative 
anomaly of $\delta^{13} \mathrm{C}_{\mathrm{DIC}}$ in the deep ocean (deeper than $\sim 2500 \mathrm{~m}$ ) found in the observation-based reconstruction by Oppo et al. (2018) was reproduced only in case of a shallower AMOC no matter what the strength of the AMOC is (expLGMss and expLGMws), which suggest that an ocean state having a shallower AMOC and northern-source deep water would be much preferable. A similar contrast between these shallower-AMOC LGM states and the deeper-AMOC LGM (expLGM) state is visible in the phosphate distribution, and again the shallower states show a much better correspondence to the reconstruction by Oppo et al. (2018), backing up the argument based on $\delta^{13} \mathrm{C}_{\mathrm{DIC}}$.

Another difference between the shallower and deeper AMOC states is found in the $\left[\mathrm{CO}_{3}^{2-}\right]$ fields in the North Atlantic. The modeled distribution of $\left[\mathrm{CO}_{3}^{2-}\right]$ in the shallower-AMOC experiments (expLGMss and expLGMws) indicates a vertical gradient between the depths of $1000 \mathrm{~m}$ and $4000 \mathrm{~m}$ that is noticeably larger than in expPI: larger by $\sim 50 \mathrm{mmol} / \mathrm{m}^{3}$ in expLGMss, and by $\sim 70 \mathrm{mmol} / \mathrm{m}^{3}$ in expLGMws, while only by $\sim 10 \mathrm{mmol} / \mathrm{m}^{3}$ in expLGM. The reconstruction by Yu et al. (2020) shows a $\sim 50-\mathrm{mmol} / \mathrm{m}^{3}$ larger vertical gradient for the LGM in the North Atlantic, which again supports the modeled states with a shallower AMOC. An increase of the vertical gradient by a similar magnitude is also reported by Chalk et al. (2019). The increased vertical contrast in expLGMss and expLGMws is brought about mainly by more efficient storage of carbon due to a more stagnant abyssal water. Contrary to the vertical gradient, however, the LGM experiments in this study overestimate

15 the values of $\left[\mathrm{CO}_{3}^{2-}\right]$ themselves in the North Atlantic by $20-50 \mathrm{mmol} / \mathrm{m}^{3}$ compared to Yu et al. (2020). This would be, at least partly, due to the uniformly increased alkalinity because such a systematic bias does not appear clearly in expPI. In the Southern Ocean, the same dataset by Yu et al. (2020) shows a slightly higher $\left[\mathrm{CO}_{3}^{2-}\right]$ (by $10-20 \mathrm{mmol} / \mathrm{m}^{3}$ ) in the bottom water for the LGM than for the modern, also supporting the results of expLGMss and expLGMws. On the other hand, the negative anomaly of $\left[\mathrm{CO}_{3}^{2-}\right]$ in the South Atlantic caused by the expanded Glacial Pacific Deep Water proposed by Yu et al. (2020) is not reproduced in the experiments in this study.

This study utilized the properties of upper sediments with regard to $\mathrm{CaCO}_{3}$ burial as a further criterion to distinguish among different physical ocean states. The preservation or dissolution of $\mathrm{CaCO}_{3}$ in ocean-floor sediments is strongly affected by the carbonate chemistry of the surrounding seawater. Therefore, the degree of $\mathrm{CaCO}_{3}$ preservation that is observed in the sediments is expected to contain local information on the properties of the seawater above the sediments. Although in this context the solid weight fraction of $\mathrm{CaCO}_{3}$ is a typical measure of the model-data fit, interpretation is not always straightforward because it is also affected by the amount of other solid species in the sediment. For example, even if the amount of $\mathrm{CaCO}_{3}$ does not change, the increased dust input during the LGM would reduce the corresponding $\mathrm{CaCO}_{3}$ weight fraction by "diluting" the contribution of $\mathrm{CaCO}_{3}$. On the contrary, the MAR would not be affected by other solid components. In expLGMws, the $\mathrm{CaCO}_{3} \mathrm{MAR}$ in the North Atlantic Ocean $\left(40-65^{\circ} \mathrm{N}\right)$ is lower than in expPI (Fig. 6) although the higher $\left[\mathrm{CO}_{3}^{2-}\right.$ ] in the bottom 30 water is an advantage for the preservation of $\mathrm{CaCO}_{3}$ in the upper sediments (Fig. 4g-i). This fact suggests that the negative anomaly in the $\mathrm{CaCO}_{3}$ MAR in that region is controlled by the supply of $\mathrm{CaCO}_{3}$ to the sediments rather than its preservation, and it reflects a direct influence of the different (i.e. weaker) magnitude of vertical mixing by local deep convection leading to a lower supply of nutrients to the surface. Although the strength of deep convection is not directly related to the intensity of the meridional transport, a weaker convection may suggest a lower sea-surface density in the North Atlantic Ocean in some way, 
https://doi.org/10.5194/cp-2022-8

Preprint. Discussion started: 14 February 2022

(C) Author(s) 2022. CC BY 4.0 License.

\section{(c) (i)}

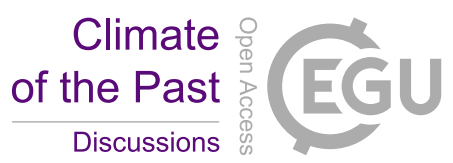

and coincide with a reduced rate of meridional transport, considering the positive correlation between the AMOC strength and the meridional density gradient across the Atlantic Ocean (e.g., Rahmstorf, 1996).

In the LGM simulations of this study, the global carbon export by biological production is broadly similar to that in expPI (Table 3), which is in agreement with the estimates by previous model-based studies (Bopp et al., 2003; Tagliabue et al., 2009;

5 Oka et al., 2011; Schmittner and Somes, 2016). The regional characteristic features of the modeled LGM carbon export (Section 3.3) are well supported by other proxy-based studies. The increased nitrate consumption and carbon export in the Southern Ocean are consistent with the estimate of glacial nutrient consumption based on nitrogen isotope ratios [e.g.,][]M-Gea2014, KC2017, Wea2017. Moreover, the decreased productivity in the northern North Atlantic Ocean observed in expLGMws is in accordance with a reconstruction based on the analysis of dinocyst assemblages (Radi and de Vernal, 2008). This reconstruction suggests an annual productivity lower by $50-150 \mathrm{gC} / \mathrm{m}^{2}$ during the LGM, which is reproduced reasonably well in the experiment. As discussed in the previous paragraph, the reduced productivity is also consistent with the MAR data.

\subsection{Relationship between the DIC concentrations and water-mass ages}

The estimates of the DIC inventories in the deep ocean during the LGM that we used in this study for model calibration are based on the assumption that there is a linear relationship between the local water age and DIC concentrations in the modern deep ocean below the depth of $2000 \mathrm{~m}$ that is also applicable to the glacial ocean (Sarnthein et al., 2013). The same assumption is employed in another study for estimating the size of the deep-ocean carbon pool (Skinner et al., 2015). An analogous linear relationship also appears in our model results from the pre-industrial run (Fig. 8a). It turns out, however, that the LGM model oceans have a different structure of the DIC-age relationship (Fig. 8b-d): in the Pacific and Southern Oceans the slope of the linear regression line is less steep and the intercept is substantially larger, while in the Atlantic Ocean it clearly has a steeper slope and a comparable intercept.

The reasons for the different structures are twofold. First, the remarkably different slopes of the regression lines for the Atlantic Ocean and the other two oceans are caused by the DIC enrichment of the southern-sourced deep water due to the reinforcement of the biological soft-tissue pump by the increased dust input to the high-latitude Southern Ocean. The carbonrich southern-sourced deep water strongly influences the Southern and Pacific Oceans, so that these two oceans are generally high in DIC compared to the modern deep water of a similar age. On the other hand, the properties of the Atlantic water can be explained by the mixing of northern-sourced water and the DIC-enriched southern-sourced water, leading to the apparent steeper gradient for the Atlantic Ocean.

The separation of the Atlantic branch from the others (Fig. 8b-d) becomes invisible by confining the depth domain to deeper ranges, so that an overall linear relationship with a relatively similar slope as in the modern case is obtained. The mixing effect becomes invisible in similar scatter plots but for water deeper than $3000 \mathrm{~m}$ for the LGM simulations with a shallower AMOC (Fig. 8g,h), while the northern-sourced component still emerges in the LGM run with a deeper AMOC (Fig. 8f) because the northern-sourced water reaches the depth of $3000 \mathrm{~m}$. In the pre-industrial setting, a very similar relationship is still valid also for the water deeper than $3000 \mathrm{~m}$ (Fig. 8e). 
https://doi.org/10.5194/cp-2022-8

Preprint. Discussion started: 14 February 2022

(c) Author(s) 2022. CC BY 4.0 License.

\section{(c) (i)}

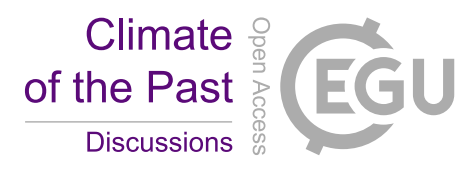

Besides the influence of the enriched southern-sourced water, as a second factor, the prior addition of mean DIC to the entire ocean in the LGM simulations would raise the regression lines uniformly. Considering a possible alteration of the DIC-age correlation induced by these two factors, applying the modern regression line to the glacial condition does not necessarily provide an accurate estimate of the glacial mean DIC concentration in the deep ocean.

5 In the instances of this study, the DIC concentration according to the modern regression line (Fig. 8a) and those based on the glacial lines (Fig. 8b-d) are different approximately by $100-150 \mathrm{mmol} / \mathrm{m}^{3}$ when the mean age of deep water is 1500 years to 2000 years. More than half of the difference is caused by the modified mean DIC concentration in the entire ocean (see Table 1), and the rest results from the carbon enrichment due to the increased biological pump. Unfortunately it is not straightforward to fix the "true" DIC-age relationship for the LGM because the magnitude of the two influencing factors, especially the mean DIC offset, is uncertain. In the framework of this study, we adjusted the mean total alkalinity so that it was compatible with the prescribed mean DIC and the 190 ppm in the atmosphere. Although this means that the mean DIC concentration, in turn, can be tuned to yield the $190 \mathrm{ppm}$ with a prescribed alkalinity inventory, it would be also difficult to have a reliable estimate of the alkalinity inventory during the LGM due to the large uncertainty of the observation-based estimate of the alkalinity budget by the post-glacial $\mathrm{CaCO}_{3}$ deposition (see Section 4.1).

\section{Conclusions and outlook}

Three time-slice simulations for the LGM with a comprehensive Earth-system model including a global carbon cycle module were carried out, so that reasonable biogeochemical states in terms of the fit to paleoclimatological and paleoceanographic records have been achieved by tuning of the total inventories of DIC and alkalinity in the ocean. They are expected to serve as an initial state for future transient simulations of the last deglaciation, taking the climate from its glacial (LGM) state to its interglacial (PI) state. In terms of biogeochemical tracer distributions in the ocean, our results clearly show that the LGM ocean states with a shallower AMOC are characterized by tracer distributions that can be more easily reconciled with the relevant observations as suggested by various previous studies. Model-data comparisons regarding $\mathrm{CaCO}_{3}$ properties in the upper sediments add further support to a state with a weaker and shallower AMOC rather than a stronger circulation, although they do not constrain directly the magnitude of the volume transport.

The examination of the balance of the bulk ALK and DIC budgets shows that all the LGM simulations in this study are likely to be compatible with the PI state within the uncertainties of the available constraints, at least from a "mass balance" point of view. The question whether they would indeed reach the PI state following a realistic trajectory would need to be examined in a transient context, because the trajectory would depend on the timing and magnitude of the deglacial sea-level rise that governs the post-glacial deposition on the shelves. Considering that the sea-level rise is a direct consequence of the ice-sheet evolution induced by climate changes, it would be fundamental to analyze and discuss the evolution of the coupled carbon cycle-ice sheet system.

As they connect these two subsystems, shelf or shallow-water processes including the weathering and deposition of biogeochemical matter and their modeling (e.g. Munhoven and François, 1996; Kölling et al., 2019; Börker et al., 2020; Lacroix 
https://doi.org/10.5194/cp-2022-8

Preprint. Discussion started: 14 February 2022

(c) Author(s) 2022. CC BY 4.0 License.

(c) (1)

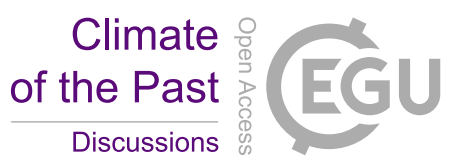

et al., 2020) would take an important role. Those processes would be fundamental to the evolution of the global carbon cycle at the glacial-interglacial timescale not only for the post-glacial evolution, but also during the evolution in the time period that preceded the LGM. The excess alkalinity was prescribed and added to the ocean in the LGM experiments of this study to satisfy independent observation-based constraints, but in reality, it would be determined as the cumulative imbalance between

5 incoming and outgoing fluxes during the course of the evolution from the penultimate interglacial period to the LGM, which will be another target of transient simulations in the future.

Code and data availability. The newly developed model source codes to tailor CESM1.2 for experiments with addiotional freshwater forcing and model output of the main experiments will be available in PANGAEA (https://www.pangaea.de/) shortly.

Author contributions. TK-N developed the model code for the additional freshwater forcing with input from UM. TK-N and AP designed 10 the experiments, and TK-N carried them out. TK-N interpreted and discus sed the results with contributions from all co-authors. AP, UM, and MS conceptualized the overarching research goal and acquired the financial support leading to this publication. TK-N prepared the manuscript with contributions from all co-authors.

Competing interests. This study has no competing interests.

Acknowledgements. This research was funded by the project PalMod (www.palmod.de; FKZ: 01LP1505D) within the framework of Research for Sustainable Development (FONA, http://fona.de) by the German Federal Ministry for Education and Research (BMBF). 
https://doi.org/10.5194/cp-2022-8

Preprint. Discussion started: 14 February 2022

(C) Author(s) 2022. CC BY 4.0 License.

\section{References}

Albani, S., Mahowald, N. M., Perry, A. T., Scanza, R. A., Zender, C. S., Heavens, N. G., Maggi, V., Kok, J. F., and Otto-Bliesner, B. L.: Improved dust representation in the Community Atmosphere Model, Journal of Advances in Modeling Earth Systems, 6, 541-570, https://doi.org/10.1002/2013MS000279, 2014.

5 Annan, J. D. and Hargreaves, J. C.: A new global reconstruction of temperature changes at the Last Glacial Maximum, Climate of the Past, 9, 367-376, https://doi.org/10.5194/cp-9-367-2013, 2013.

Archer, D., Winguth, A., Lea, D., and Mahowald, N.: What caused the glacial/interglacial atmospheric pCO $\mathrm{Cycles}_{2}$, Reviews of Geophysics, 38, 159-189, https://doi.org/10.1029/1999RG000066, 2000.

Argus, D. F., Peltier, W. R., Drummond, R., and Moore, A. W.: The Antarctica component of postglacial rebound model ICE-6G_C (VM5a) based on GPS positioning, exposure age dating of ice thicknesses, and relative sea level histories, Geophysical Journal International, 198, 537-563, https://doi.org/10.1093/gji/ggu140, 2014.

Armstrong, R. A., Lee, C., Hedges, J. I., Honjo, S., and Wakeham, S. G.: A new, mechanistic model for organic carbon fluxes in the ocean based on the quantitative association of POC with ballast minerals, Deep Sea Research Part II: Topical Studies in Oceanography, 49, 219-236, https://doi.org/10.1016/S0967-0645(01)00101-1, 2002.

Augustin, L., Barbante, C., Barnes, P. R. F., Marc Barnola, J., Bigler, M., Castellano, E., Cattani, O., Chappellaz, J., Dahl-Jensen, D., Delmonte, B., Dreyfus, G., Durand, G., Falourd, S., Fischer, H., Flückiger, J., Hansson, M. E., Huybrechts, P., Jugie, G., Johnsen, S. J., Jouzel, J., Kaufmann, P., Kipfstuhl, J., Lambert, F., Lipenkov, V. Y., Littot, G. C., Longinelli, A., Lorrain, R., Maggi, V., Masson-Delmotte, V., Miller, H., Mulvaney, R., Oerlemans, J., Oerter, H., Orombelli, G., Parrenin, F., Peel, D. A., Petit, J.-R., Raynaud, D., Ritz, C., Ruth, U., Schwander, J., Siegenthaler, U., Souchez, R., Stauffer, B., Peder Steffensen, J., Stenni, B., Stocker, T. F., Tabacco, I. E., Udisti, R., van de Wal, R. S. W., van den Broeke, M., Weiss, J., Wilhelms, F., Winther, J.-G., Wolff, E. W., and Zucchelli, M.: Eight glacial cycles from an Antarctic ice core, Nature, 429, 623-628, https://doi.org/10.1038/nature02599, 2004.

Bereiter, B., Eggleston, S., Schmitt, J., Nehrbass-Ahles, C., Stocker, T. F., Fischer, H., Kipfstuhl, S., and Chappellaz, J.: Revision of the EPICA Dome $\mathrm{C} \mathrm{CO} 2$ record from 800 to $600 \mathrm{kyr}$ before present, Geophys. Res. Lett., 42, 542-549, https://doi.org/10.1002/2014GL061957, 2015.

Berger, W.: Deglacial $\mathrm{CO}_{2}$ buildup: Constraints on the coral-reef model, Palaeogeography, Palaeoclimatology, Palaeoecology, 40, 235-253, https://doi.org/https://doi.org/10.1016/0031-0182(82)90092-X, https://www.sciencedirect.com/science/article/pii/ $003101828290092 \mathrm{X}$, paleogeography and Climate, 1982.

Bopp, L., Kohfeld, K. E., Le QuéRé, C., and Aumont, O.: Dust impact on marine biota and atmospheric $\mathrm{CO}_{2}$ during glacial periods, Paleoceanography, 18, 1046, https://doi.org/10.1029/2002PA000810, 2003.

Börker, J., Hartmann, J., Amann, T., Romero-Mujalli, G., Moosdorf, N., and Jenkins, C.: Chemical Weathering of Loess and Its Contribution to Global Alkalinity Fluxes to the Coastal Zone During the Last Glacial Maximum, Mid-Holocene, and Present, Geochemistry, Geophysics, Geosystems, 21, e2020GC008 922, https://doi.org/https://doi.org/10.1029/2020GC008922, https://agupubs.onlinelibrary.wiley. com/doi/abs/10.1029/2020GC008922, e2020GC008922 2020GC008922, 2020.

Brovkin, V., Ganopolski, A., Archer, D., and Rahmstorf, S.: Lowering of glacial atmospheric $\mathrm{CO}_{2}$ in response to changes in oceanic circulation and marine biogeochemistry, Paleoceanography, 22, PA4202, https://doi.org/10.1029/2006PA001380, 2007.

Brovkin, V., Ganopolski, A., Archer, D., and Munhoven, G.: Glacial $\mathrm{CO}_{2}$ cycle as a succession of key physical and biogeochemical processes, Climate of the Past, 8, 251-264, https://doi.org/10.5194/cp-8-251-2012, 2012. 
https://doi.org/10.5194/cp-2022-8

Preprint. Discussion started: 14 February 2022

(c) Author(s) 2022. CC BY 4.0 License.

(c) (i)

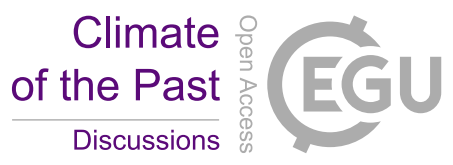

Cartapanis, O., Galbraith, E. D., Bianchi, D., and Jaccard, S. L.: Carbon burial in deep-sea sediment and implications for oceanic inventories of carbon and alkalinity over the last glacial cycle, Climate of the Past, 14, 1819-1850, https://doi.org/10.5194/cp-14-1819-2018, 2018.

Catubig, N. R., Archer, D. E., Francois, R., Demenocal, P., Howard, W., and Yu, E.-F.: Global deep-sea burial rate of calcium carbonate during the Last Glacial Maximum, Paleoceanography, 13, 298-310, https://doi.org/10.1029/98PA00609, 1998.

5 Chalk, T. B., Foster, G. L., and Wilson, P. A.: Dynamic storage of glacial $\mathrm{CO}_{2}$ in the Atlantic Ocean revealed by boron $\left[\mathrm{CO}_{3}{ }^{2-}\right]$ and $\mathrm{pH}$ records, Earth and Planetary Science Letters, 510, 1-11, https://doi.org/10.1016/j.eps1.2018.12.022, 2019.

Eyring, V., Bony, S., Meehl, G. A., Senior, C. A., Stevens, B., Stouffer, R. J., and Taylor, K. E.: Overview of the Coupled Model Intercomparison Project Phase 6 (CMIP6) experimental design and organization, Geoscientific Model Development, 9, 1937-1958, https://doi.org/10.5194/gmd-9-1937-2016, 2016.

Ganopolski, A. and Brovkin, V.: Simulation of climate, ice sheets and $\mathrm{CO}_{2}$ evolution during the last four glacial cycles with an Earth system model of intermediate complexity, Climate of the Past, 13, 1695-1716, https://doi.org/10.5194/cp-13-1695-2017, 2017.

Gu, S., Liu, Z., Oppo, D. W., Lynch-Stieglitz, J., Jahn, A., Zhang, J., and Wu, L.: Assessing the potential capability of reconstructing glacial Atlantic water masses and AMOC using multiple proxies in CESM, Earth and Planetary Science Letters, 541, 116294, https://doi.org/10.1016/j.eps1.2020.116294, 2020.

Hurrell, J. W., Holland, M. M., Gent, P. R., Ghan, S., Kay, J. E., Kushner, P. J., Lamarque, J.-F., Large, W. G., Lawrence, D., Lindsay, K., Lipscomb, W. H., Long, M. C., Mahowald, N., Marsh, D. R., Neale, R. B., Rasch, P., Vavrus, S., Vertenstein, M., Bader, D., Collins, W. D., Hack, J. J., Kiehl, J., and Marshall, S.: The Community Earth System Model: A Framework for Collaborative Research, Bulletin of the American Meteorological Society, 94, 1339-1360, https://doi.org/10.1175/BAMS-D-12-00121.1, 2013.

Husson, L., Pastier, A.-M., Pedoja, K., Elliot, M., Paillard, D., Authemayou, C., Sarr, A.-C., Schmitt, A., and Cahyarini, S. Y.: Reef Carbonate Productivity During Quaternary Sea Level Oscillations, Geochemistry, Geophysics, Geosystems, 19, 1148-1164, https://doi.org/https://doi.org/10.1002/2017GC007335, https://agupubs.onlinelibrary.wiley.com/doi/abs/10.1002/2017GC007335, 2018.

Jahn, A., Lindsay, K., Giraud, X., Gruber, N., Otto-Bliesner, B. L., Liu, Z., and Brady, E. C.: Carbon isotopes in the ocean model of the Community Earth System Model (CESM1), Geoscientific Model Development, 8, 2419-2434, https://doi.org/10.5194/gmd-8-2419-2015, 2015 .

Kageyama, M., Albani, S., Braconnot, P., Harrison, S. P., Hopcroft, P. O., Ivanovic, R. F., Lambert, F., Marti, O., Peltier, W. R., Peterschmitt, J.-Y., Roche, D. M., Tarasov, L., Zhang, X., Brady, E. C., Haywood, A. M., LeGrande, A. N., Lunt, D. J., Mahowald, N. M., Mikolajewicz, U., Nisancioglu, K. H., Otto-Bliesner, B. L., Renssen, H., Tomas, R. A., Zhang, Q., Abe-Ouchi, A., Bartlein, P. J., Cao, J., Li, Q., Lohmann, G., Ohgaito, R., Shi, X., Volodin, E., Yoshida, K., Zhang, X., and Zheng, W.: The PMIP4 contribution to CMIP6 - Part 4: Scientific objectives and experimental design of the PMIP4-CMIP6 Last Glacial Maximum experiments and PMIP4 sensitivity experiments, Geoscientific Model Development, 10, 4035-4055, https://doi.org/10.5194/gmd-10-4035-2017, https://gmd.copernicus.org/articles/10/4035/2017/, 2017.

Kemppinen, K. M. S., Holden, P. B., Edwards, N. R., Ridgwell, A., and Friend, A. D.: Coupled climate-carbon cycle simulation of the Last Glacial Maximum atmospheric $\mathrm{CO}_{2}$ decrease using a large ensemble of modern plausible parameter sets, Climate of the Past, 15 , 1039-1062, https://doi.org/10.5194/cp-15-1039-2019, https://cp.copernicus.org/articles/15/1039/2019/, 2019.

Kohfeld, K. E. and Chase, Z.: Temporal evolution of mechanisms controlling ocean carbon uptake during the last glacial cycle, Earth and Planetary Science Letters, 472, 206-215, https://doi.org/10.1016/j.eps1.2017.05.015, 2017. 
https://doi.org/10.5194/cp-2022-8

Preprint. Discussion started: 14 February 2022

(C) Author(s) 2022. CC BY 4.0 License.

(c) (i)

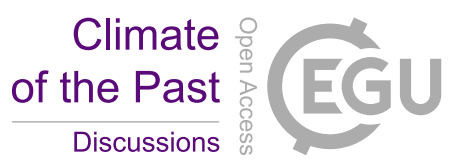

Köhler, P. and Munhoven, G.: Late Pleistocene Carbon Cycle Revisited by Considering Solid Earth Processes, Paleoceanography and Paleoclimatology, 35, e2020PA004 020, https://doi.org/https://doi.org/10.1029/2020PA004020, https://agupubs.onlinelibrary.wiley.com/doi/ abs/10.1029/2020PA004020, e2020PA004020 10.1029/2020PA004020, 2020.

Köhler, P., Nehrbass-Ahles, C., Schmitt, J., Stocker, T. F., and Fischer, H.: A 156 kyr smoothed history of the atmospheric greenhouse gases $\mathrm{CO}_{2}, \mathrm{CH}_{4}$, and $\mathrm{N}_{2} \mathrm{O}$ and their radiative forcing, Earth System Science Data, 9, 363-387, https://doi.org/10.5194/essd-9-363-2017, https://essd.copernicus.org/articles/9/363/2017/, 2017.

Kölling, M., Bouimetarhan, I., Bowles, M. W., Felis, T., Goldhammer, T., Hinrichs, K.-U., Schulz, M., and Zabel, M.: Consistent CO 2 release by pyrite oxidation on continental shelves prior to glacial terminations, Nature Geoscience, 12, 929-934, https://doi.org/10.1038/s41561019-0465-9, 2019.

Kurahashi-Nakamura, T., Paul, A., and Losch, M.: Dynamical reconstruction of the global ocean state during the Last Glacial Maximum, Paleoceanography, 32, 326-350, https://doi.org/10.1002/2016PA003001, 2017.

Kurahashi-Nakamura, T., Paul, A., Munhoven, G., Merkel, U., and Schulz, M.: Coupling of a sediment diagenesis model (MEDUSA) and an Earth system model (CESM1.2): a contribution toward enhanced marine biogeochemical modelling and long-term climate simulations, Geoscientific Model Development, 13, 825-840, https://doi.org/10.5194/gmd-13-825-2020, 2020.

Lacroix, F., Ilyina, T., and Hartmann, J.: Oceanic $\mathrm{CO}_{2}$ outgassing and biological production hotspots induced by pre-industrial river loads of nutrients and carbon in a global modeling approach, Biogeosciences, 17, 55-88, https://doi.org/10.5194/bg-17-55-2020, https://bg. copernicus.org/articles/17/55/2020/, 2020.

Lindsay, K., Bonan, G. B., Doney, S. C., Hoffman, F. M., Lawrence, D. M., Long, M. C., Mahowald, N. M., Keith Moore, J., Randerson, J. T., and Thornton, P. E.: Preindustrial-Control and Twentieth-Century Carbon Cycle Experiments with the Earth System Model CESM1(BGC), Journal of Climate, 27, 8981-9005, https://doi.org/10.1175/JCLI-D-12-00565.1, 2014.

Martínez-García, A., Sigman, D. M., Ren, H., Anderson, R. F., Straub, M., Hodell, D. A., Jaccard, S. L., Eglinton, T. I., and Haug, G. H.: Iron Fertilization of the Subantarctic Ocean During the Last Ice Age, Science, 343, 1347-1350, https://doi.org/10.1126/science.1246848, 2014.

Menviel, L., Yu, J., Joos, F., Mouchet, A., Meissner, K. J., and England, M. H.: Poorly ventilated deep ocean at the Last Glacial Maximum inferred from carbon isotopes: A data-model comparison study, Paleoceanography, 32, 2-17, https://doi.org/10.1002/2016PA003024, 2017.

Merino, N., Le Sommer, J., Durand, G., Jourdain, N. C., Madec, G., Mathiot, P., and Tournadre, J.: Antarctic icebergs melt over the Southern Ocean : Climatology and impact on sea ice, Ocean Modelling, 104, 99-110, https://doi.org/10.1016/j.ocemod.2016.05.001, 2016.

Milliman, J. D.: Production and accumulation of calcium carbonate in the ocean: Budget of a nonsteady state, Global Biogeochemical Cycles, 7, 927-957, https://doi.org/https://doi.org/10.1029/93GB02524, https://agupubs.onlinelibrary.wiley.com/doi/abs/10.1029/ 93GB02524, 1993.

Moore, J. K., Doney, S. C., and Lindsay, K.: Upper ocean ecosystem dynamics and iron cycling in a global three-dimensional model, Global Biogeochemical Cycles, 18, GB4028, https://doi.org/10.1029/2004GB002220, 2004.

Moore, J. K., Lindsay, K., Doney, S. C., Long, M. C., and Misumi, K.: Marine Ecosystem Dynamics and Biogeochemical Cycling in the Community Earth System Model [CESM1(BGC)]: Comparison of the 1990s with the 2090s under the RCP4.5 and RCP8.5 Scenarios, Journal of Climate, 26, 9291-9312, https://doi.org/10.1175/JCLI-D-12-00566.1, 2013.

Muglia, J. and Schmittner, A.: Carbon isotope constraints on glacial Atlantic meridional overturning: Strength vs depth, Quaternary Science Reviews, 257, 106844, https://doi.org/10.1016/j.quascirev.2021.106844, 2021. 
https://doi.org/10.5194/cp-2022-8

Preprint. Discussion started: 14 February 2022

(C) Author(s) 2022. CC BY 4.0 License.

(c) (i)

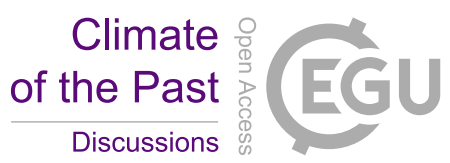

Muglia, J., Skinner, L. C., and Schmittner, A.: Weak overturning circulation and high Southern Ocean nutrient utilization maximized glacial ocean carbon, Earth and Planetary Science Letters, 496, 47-56, https://doi.org/10.1016/j.eps1.2018.05.038, 2018.

Munhoven, G.: Mathematics of the total alkalinity-pH equation - pathway to robust and universal solution algorithms: the SolveSAPHE package v1.0.1, Geoscientific Model Development, 6, 1367-1388, https://doi.org/10.5194/gmd-6-1367-2013, https://gmd.copernicus.org/ articles/6/1367/2013/, 2013.

Munhoven, G.: Model of Early Diagenesis in the Upper Sediment with Adaptable complexity - MEDUSA (v. 2): a time-dependent biogeochemical sediment module for Earth System Models, process analysis and teaching, Geoscientific Model Development Discussions, 2020, 1-40, https://doi.org/10.5194/gmd-2020-309, https://gmd.copernicus.org/preprints/gmd-2020-309/, 2020.

Munhoven, G. and François, L. M.: Glacial-interglacial variability of atmospheric $\mathrm{CO}_{2}$ due to changing continental silicate rock weathering: A model study, Journal of Geophysical Research: Atmospheres, 101, 21 423-21 437, https://doi.org/https://doi.org/10.1029/96JD01842, https://agupubs.onlinelibrary.wiley.com/doi/abs/10.1029/96JD01842, 1996.

Oka, A., Abe-Ouchi, A., Chikamoto, M. O., and Ide, T.: Mechanisms controlling export production at the LGM: Effects of changes in oceanic physical fields and atmospheric dust deposition, Global Biogeochemical Cycles, 25, GB2009, https://doi.org/10.1029/2009GB003628, 2011.

Opdyke, B. N.: Shallow Water Carbonate Deposition and Its Effect on the Carbon Cycle, pp. 161-168, Cambridge University Press, https://doi.org/10.1017/CBO9780511573095.015, 2000.

Opdyke, B. N. and Walker, J. C.: Return of the coral reef hypothesis: Basin to shelf partitioning of $\mathrm{CaCO}_{3}$ and its effect on atmospheric $\mathrm{CO}_{2}$, Geology, 20, 733-736, https://doi.org/10.1130/0091-7613(1992)020<0733:ROTCRH>2.3.CO;2, https://doi.org/10.1130/ 0091-7613(1992)020<0733:ROTCRH>2.3.CO;2, 1992.

Oppo, D. W., Gebbie, G., Huang, K.-F., Curry, W. B., Marchitto, T. M., and Pietro, K. R.: Data Constraints on Glacial Atlantic Water Mass Geometry and Properties, Paleoceanography and Paleoclimatology, 33, 1013-1034, https://doi.org/10.1029/2018PA003408, https: //agupubs.onlinelibrary.wiley.com/doi/abs/10.1029/2018PA003408, 2018.

Paul, A., Mulitza, S., Stein, R., and Werner, M.: A global climatology of the ocean surface during the Last Glacial Maximum mapped on a regular grid (GLOMAP), Climate of the Past, 17, 805-824, https://doi.org/10.5194/cp-17-805-2021, https://cp.copernicus.org/articles/17/ 805/2021/, 2021.

Peltier, W. R., Argus, D. F., and Drummond, R.: Space geodesy constrains ice age terminal deglaciation: The global ICE-6G_C (VM5a) model, Journal of Geophysical Research (Solid Earth), 120, 450-487, https://doi.org/10.1002/2014JB011176, 2015.

Petit, J. R., Jouzel, J., Raynaud, D., Barkov, N. I., Barnola, J.-M., Basile, I., Bender, M., Chappellaz, J., Davis, M., Delaygue, G., Delmotte, M., Kotlyakov, V. M., Legrand, M., Lipenkov, V. Y., Lorius, C., Pépin, L., Ritz, C., Saltzman, E., and Stievenard, M.: Climate and atmospheric history of the past 420,000 years from the Vostok ice core, Antarctica, Nature, 399, 429-436, https://doi.org/10.1038/20859, 1999.

Radi, T. and de Vernal, A.: Last glacial maximum (LGM) primary productivity in the northern North Atlantic Ocean, Canadian Journal of Earth Sciences, 45, 1299-1316, https://doi.org/10.1139/E08-059, 2008.

Rahmstorf, S.: On the freshwater forcing and transport of the Atlantic thermohaline circulation, Climate Dynamics, 12, 799-811, https://doi.org/10.1007/s003820050144, 1996.

Ridgwell, A. J., Watson, A. J., Maslin, M. A., and Kaplan, J. O.: Implications of coral reef buildup for the controls on atmospheric $\mathrm{CO}_{2}$ since the Last Glacial Maximum, Paleoceanography, 18, 1083, https://doi.org/10.1029/2003PA000893, 2003. 
https://doi.org/10.5194/cp-2022-8

Preprint. Discussion started: 14 February 2022

(C) Author(s) 2022. CC BY 4.0 License.

(c) (i)

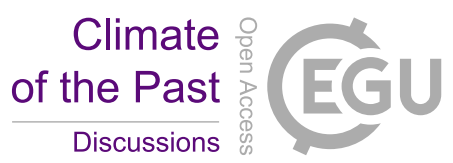

Sarnthein, M., Schneider, B., and Grootes, P. M.: Peak glacial ${ }^{14} \mathrm{C}$ ventilation ages suggest major draw-down of carbon into the abyssal ocean, Climate of the Past, 9, 2595-2614, https://doi.org/10.5194/cp-9-2595-2013, 2013.

Schmitt, J., Schneider, R., Elsig, J., Leuenberger, D., Lourantou, A., Chappellaz, J., Köhler, P., Joos, F., Stocker, T. F., Leuenberger, M., and Fischer, H.: Carbon Isotope Constraints on the Deglacial $\mathrm{CO}_{2}$ Rise from Ice Cores, Science, 336, 711, https://doi.org/10.1126/science.1217161, 2012.

Schmittner, A. and Somes, C. J.: Complementary constraints from carbon $\left({ }^{13} \mathrm{C}\right)$ and nitrogen $\left({ }^{15} \mathrm{~N}\right)$ isotopes on the glacial ocean's soft-tissue biological pump, Paleoceanography, 31, 669-693, https://doi.org/10.1002/2015PA002905, 2016.

Shields, C. A., Bailey, D. A., Danabasoglu, G., Jochum, M., Kiehl, J. T., Levis, S., and Park, S.: The Low-Resolution CCSM4, Journal of Climate, 25, 3993-4014, https://doi.org/10.1175/JCLI-D-11-00260.1, 2012.

Skinner, L., McCave, I., Carter, L., Fallon, S., Scrivner, A., and Primeau, F.: Reduced ventilation and enhanced magnitude of the deep Pacific carbon pool during the last glacial period, Earth and Planetary Science Letters, 411, 45-52, https://doi.org/https://doi.org/10.1016/j.epsl.2014.11.024, https://www.sciencedirect.com/science/article/pii/S0012821X1400716X, 2015.

Tagliabue, A., Bopp, L., Roche, D. M., Bouttes, N., Dutay, J.-C., Alkama, R., Kageyama, M., Michel, E., and Paillard, D.: Quantifying the roles of ocean circulation and biogeochemistry in governing ocean carbon-13 and atmospheric carbon dioxide at the last glacial maximum, Climate of the Past, 5, 695-706, 2009.

Tierney, J. E., Zhu, J., King, J., Malevich, S. B., Hakim, G. J., and Poulsen, C. J.: Glacial cooling and climate sensitivity revisited, Nature, 584, 569-573, https://doi.org/10.1038/s41586-020-2617-x, 2020.

Vecsei, A. and Berger, W. H.: Increase of atmospheric CO2 during deglaciation: Constraints on the coral reef hypothesis from patterns of deposition, Global Biogeochemical Cycles, 18, GB1035, https://doi.org/https://doi.org/10.1029/2003GB002147, https://agupubs onlinelibrary.wiley.com/doi/abs/10.1029/2003GB002147, 2004.

Wang, X. T., Sigman, D. M., Prokopenko, M. G., Adkins, J. F., Robinson, L. F., Hines, S. K., Chai, J., Studer, A. S., Martínez-García, A., Chen, T., and Haug, G. H.: Deep-sea coral evidence for lower Southern Ocean surface nitrate concentrations during the last ice age, Proceedings of the National Academy of Science, 114, 3352-3357, https://doi.org/10.1073/pnas.1615718114, 2017.

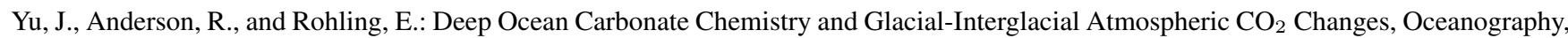
27, 16-25, https://doi.org/https://doi.org/10.5670/oceanog.2014.04, 2014.

Yu, J., Menviel, L., Jin, Z. D., Anderson, R. F., Jian, Z., Piotrowski, A. M., Ma, X., Rohling, E. J., Zhang, F., Marino, G., and McManus, J. F.: Last glacial atmospheric $\mathrm{CO}_{2}$ decline due to widespread Pacific deep-water expansion, Nature Geoscience, 13, 628-633, https://doi.org/10.1038/s41561-020-0610-5, 2020. 
https://doi.org/10.5194/cp-2022-8

Preprint. Discussion started: 14 February 2022

(C) Author(s) 2022. CC BY 4.0 License.

Climate
of the Past
Discussions

Table 1. Overview of the experimental designs in this study

\begin{tabular}{lrrrrr}
\hline experiments & general setting & $\begin{array}{r}\text { FW forcing } \\
\text { in N-ATL }\end{array}$ & $\begin{array}{r}\text { FW forcing }^{1} \\
\text { in } \mathrm{SO}^{1} \\
(\mathrm{~Sv})\end{array}$ & $\begin{array}{r}\text { prior addition } \\
\text { of mean DIC } \\
\left(\mathrm{mmol} / \mathrm{m}^{3}\right)\end{array}$ & $\begin{array}{r}\text { prior addition } \\
\text { of mean ALK } \\
\left(\mathrm{meq} / \mathrm{m}^{3}\right)\end{array}$ \\
\hline expPI & DECK $^{2}$ & - & - & - & - \\
expLGM & PMIP4 & - & - & 94 & 80 \\
expLGMws & PMIP4 & +0.1 & - & 72 & 60 \\
expLGMss & PMIP4 & -0.1 & -0.25 & 75 & 40 \\
\hline 1: see also Fig. 1 & & & & & \\
2: Eyring et al. (2016) & & & & & \\
3: Kageyama et al. (2017) & & & & &
\end{tabular}


https://doi.org/10.5194/cp-2022-8

Preprint. Discussion started: 14 February 2022

(C) Author(s) 2022. CC BY 4.0 License.

(c) (i)

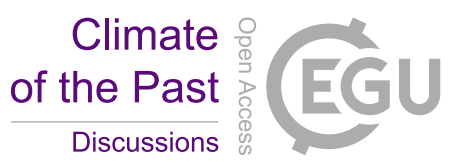

Table 2. The first-guess adjustment of the global mean concentrations of DIC and total alkalinity for the preparatory runs, and the resultant DIC anomaly averaged over the depths below $2000 \mathrm{~m}$. In the last column, the differences between each of the LGM runs and expPI that are averaged over the last 50 years are shown.

\begin{tabular}{lrrr}
\hline experiments & $\begin{array}{r}\text { prior addition } \\
\text { of average DIC } \\
\left(\mathrm{mmol} / \mathrm{m}^{3}\right)\end{array}$ & $\begin{array}{r}\text { prior addition } \\
\text { of average ALK } \\
\left(\mathrm{mmol} / \mathrm{m}^{3}\right)\end{array}$ & $\begin{array}{r}\text { posterior DIC anomaly } \\
\text { below } 2000 \mathrm{~m} \\
\left(\mathrm{mmol} / \mathrm{m}^{3}\right)\end{array}$ \\
\hline prepLGM & 100 & 88 & 106 \\
prepLGMws & 100 & 100 & 128 \\
prepLGMss & 100 & 75 & 125 \\
\hline
\end{tabular}


https://doi.org/10.5194/cp-2022-8

Preprint. Discussion started: 14 February 2022

(C) Author(s) 2022. CC BY 4.0 License.

(c) (i)

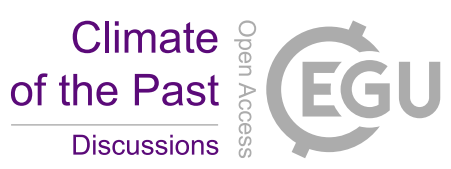

Table 3. Biogeochemical properties of the model states (the last 50-years average) in this study. For DIC, the anomaly is globally averaged over the depths below $2000 \mathrm{~m}$ and shows the difference between each of the LGM simulations and expPI.

\begin{tabular}{lrrrr}
\hline experiments & $p \mathrm{CO}_{2}$ & $\begin{array}{r}\text { DIC anomaly } \\
\text { below } 2000 \mathrm{~m} \\
\left(\mathrm{mmol} / \mathrm{m}^{3}\right)\end{array}$ & $\begin{array}{r}\text { export }_{\text {production }^{1}} \\
\left(\mathrm{GtC} \mathrm{yr}^{-1}\right)\end{array}$ & $\begin{array}{l}\text { land C storage } \\
\end{array}$ \\
& 276 & - & 7.6 & $1.83 \times 10^{3}$ \\
\hline expPI & 185 & 109 & 7.8 & $1.49 \times 10^{3}$ \\
expLGM & 186 & 102 & 7.4 & $1.44 \times 10^{3}$ \\
expLGMws & 182 & 116 & 7.3 & $1.48 \times 10^{3}$ \\
expLGMss & 182 & & \\
\hline
\end{tabular}

1: global export production at $100-\mathrm{m}$ depth including $\mathrm{POC}$ and $\mathrm{CaCO}_{3}$ 
https://doi.org/10.5194/cp-2022-8

Preprint. Discussion started: 14 February 2022

(c) Author(s) 2022. CC BY 4.0 License.

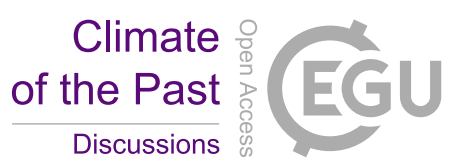

(c) (1)

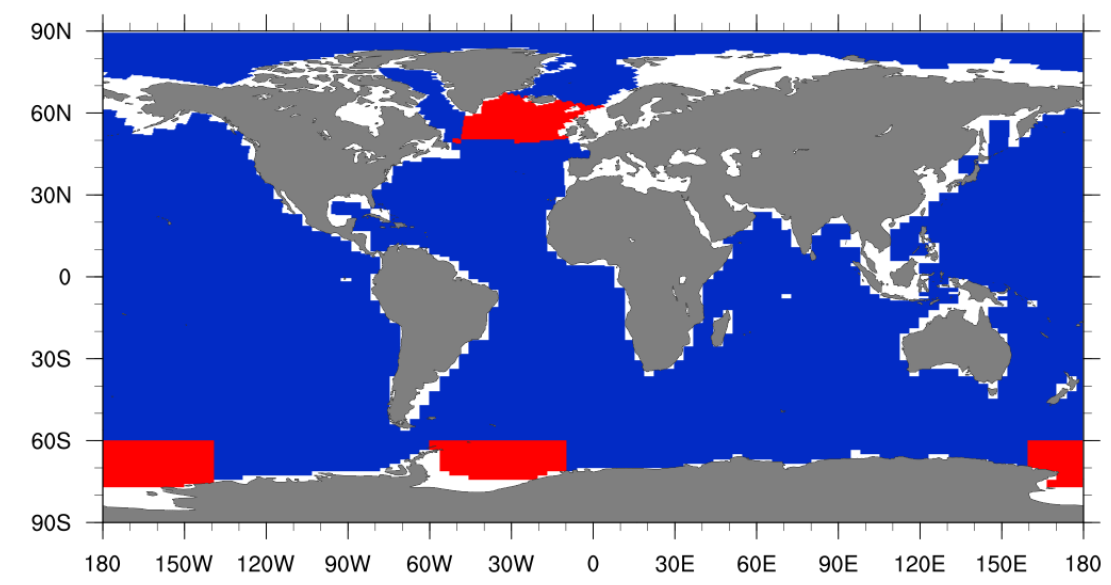

Figure 1. Regions allotted for the additional freshwater forcing (shown in red). Additional $0.1 \mathrm{~Sv}$ in total was uniformly given to the specified region in the North Atlantic for expLGMws, while, for expLGMss, 0.1 Sv and 0.25 Sv were subtracted from the North Atlantic and Southern Ocean, respectively. Corresponding compensation (i.e. freshwater flux having the opposite sign) was given to the other regions homogeneously to keep the total volume of sea water. 
https://doi.org/10.5194/cp-2022-8

Preprint. Discussion started: 14 February 2022

(C) Author(s) 2022. CC BY 4.0 License.

(c) (i)

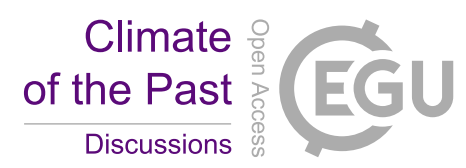

(a)

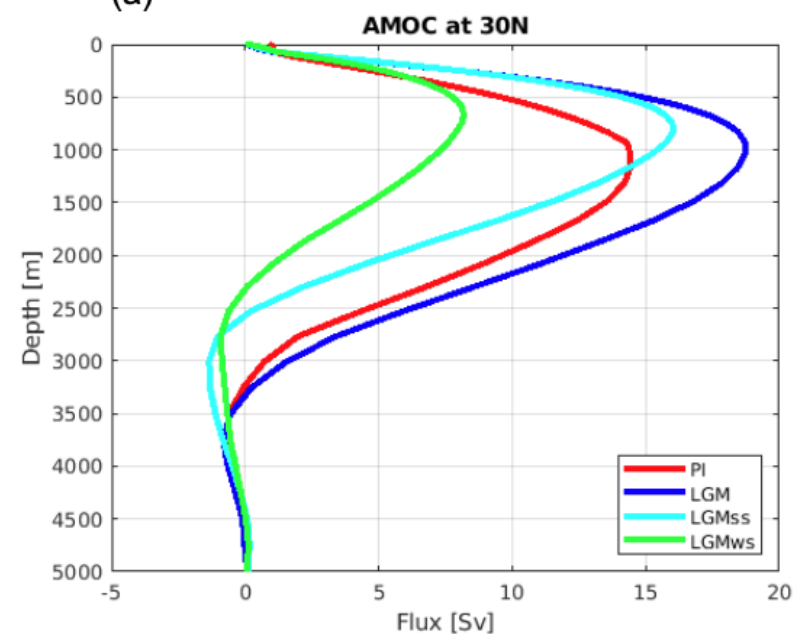

(b)

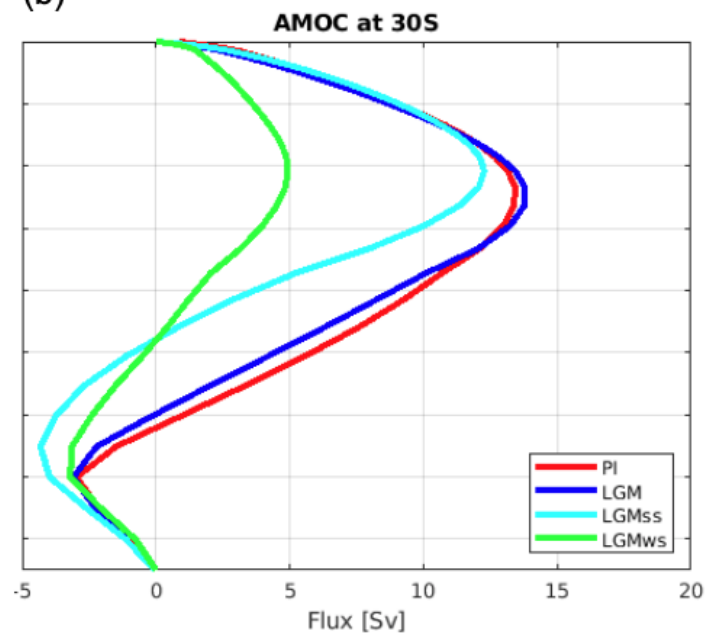

Figure 2. Vertical profile of the AMOC (a) at $30^{\circ} \mathrm{N}$ and (b) at $30^{\circ} \mathrm{S}$ for the main experiments in this study. The average states of the last 50 years are shown. 
https://doi.org/10.5194/cp-2022-8

Preprint. Discussion started: 14 February 2022

(c) Author(s) 2022. CC BY 4.0 License.

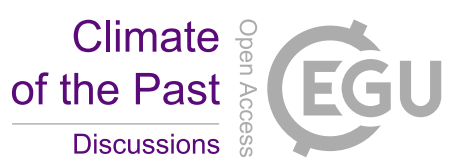

(c) (i)
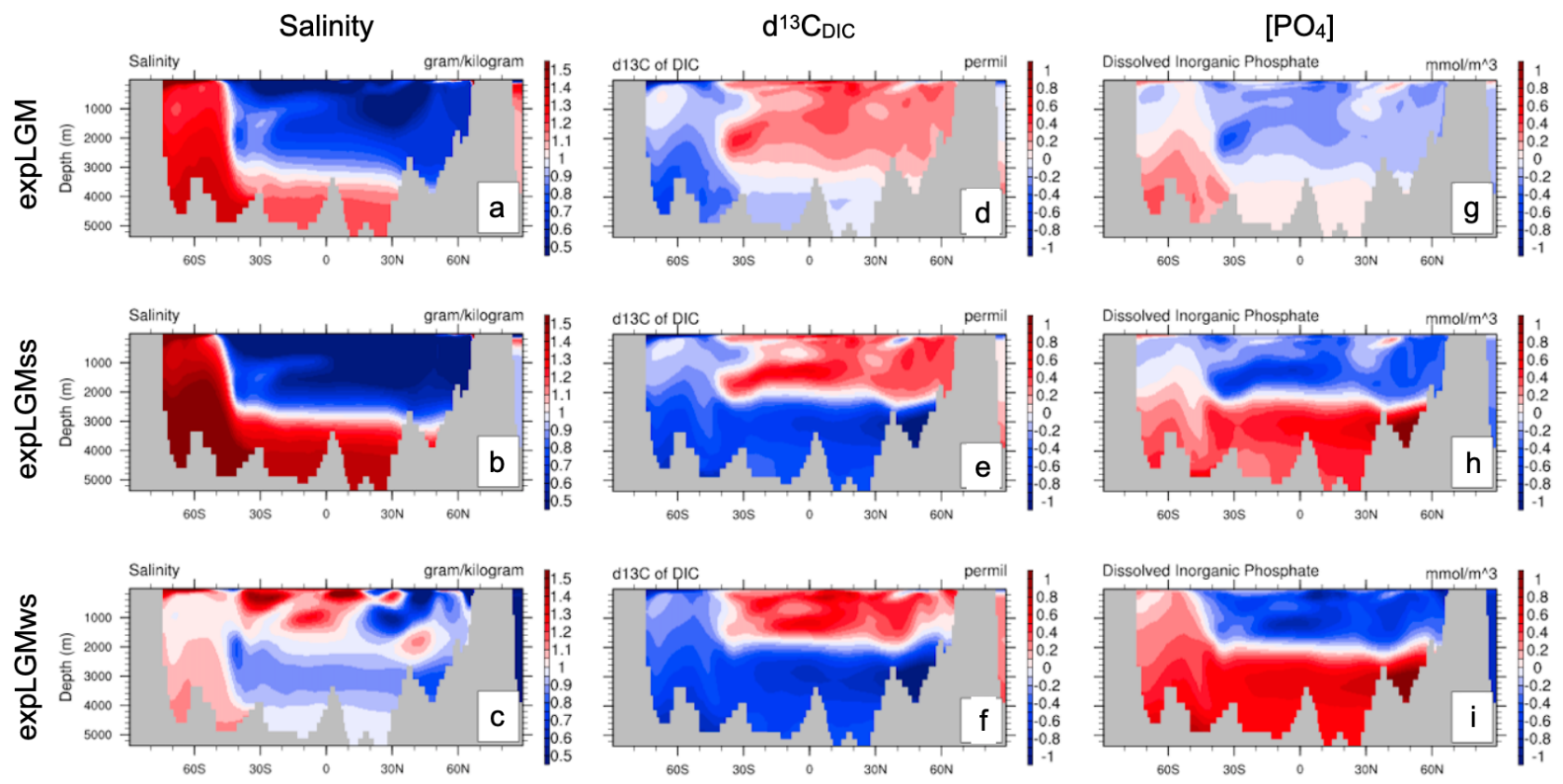

Figure 3. Meridional sections at $30^{\circ} \mathrm{W}$ of modeled tracer distributions in the LGM experiments of this study (part 1). The differences from those in expPI are shown for each of the LGM runs: expLGM (a, d, and g), expLGMss (b, e, and h), and expLGMws (c, f, and i). For the salinity, to facilitate the comparsion excluding the uniform salinity offset due to the volume effect, 1.0 is centered on the color scale. The average states in the last 50 years are shown. 
https://doi.org/10.5194/cp-2022-8

Preprint. Discussion started: 14 February 2022

(c) Author(s) 2022. CC BY 4.0 License.

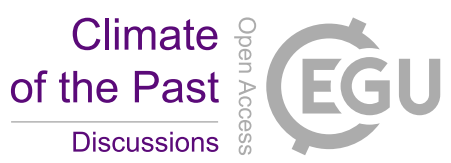

(c) (i)
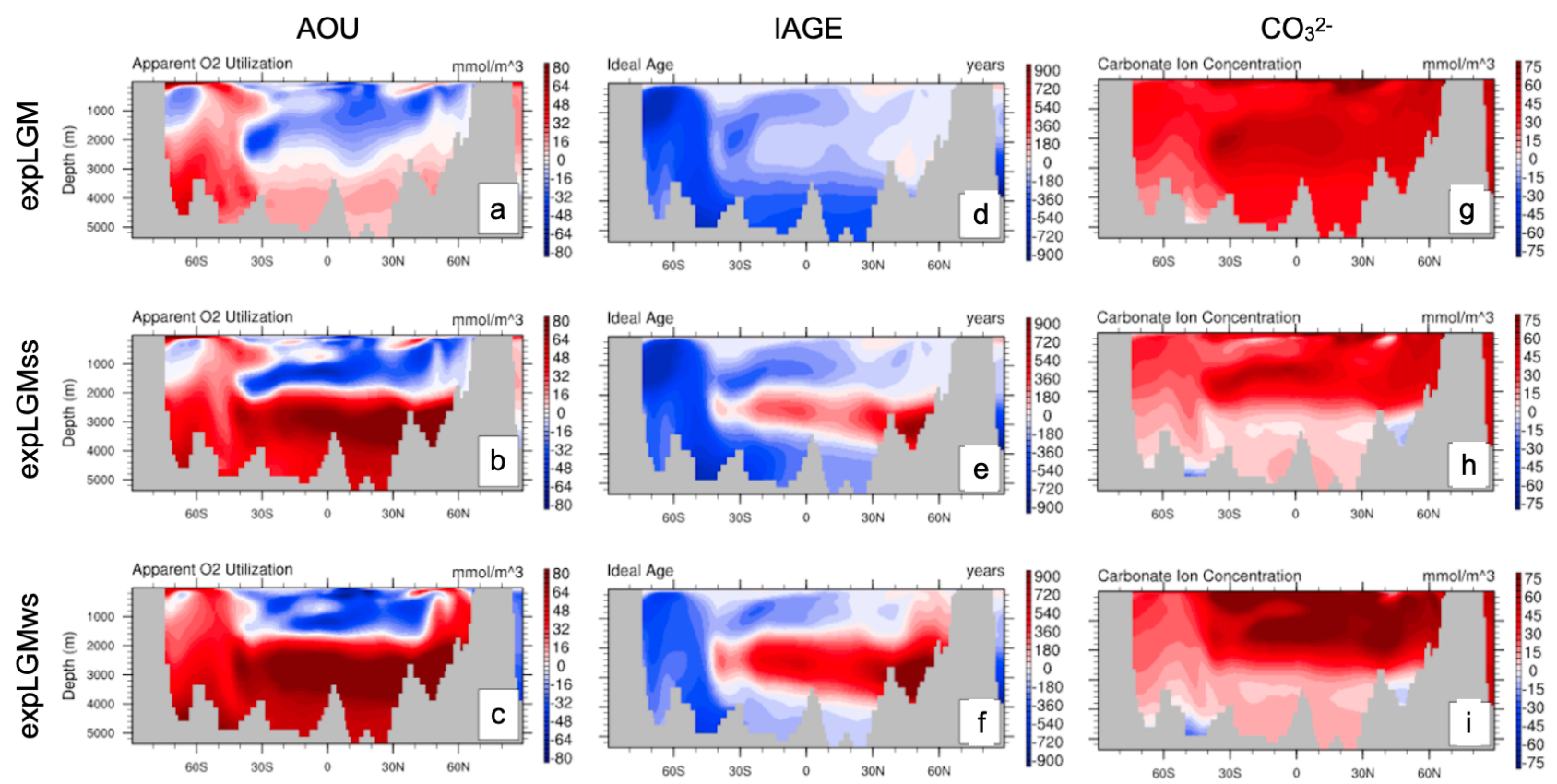

Figure 4. Meridional sections at $30^{\circ} \mathrm{W}$ of modelled tracer distributions in the LGM experiments of this study (part 2). The differences from those in expPI are shown for each of the LGM runs: expLGM (a, d, and g), expLGMss (b, e, and h), and expLGMws (c, f, and i). The average states in the last 50 years are shown. 


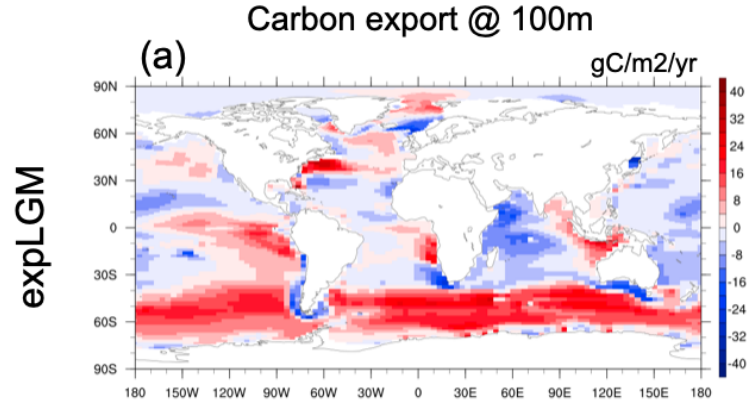

(b)

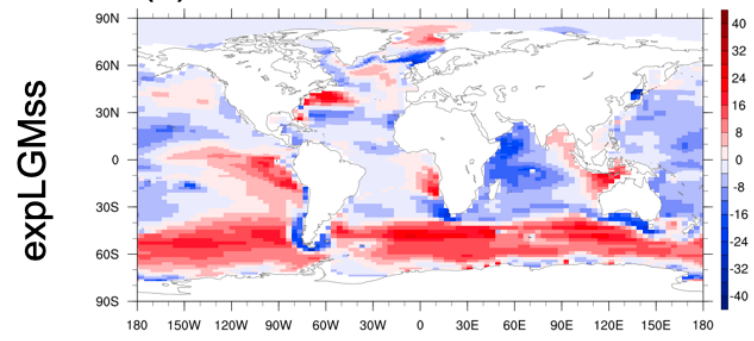

(c)

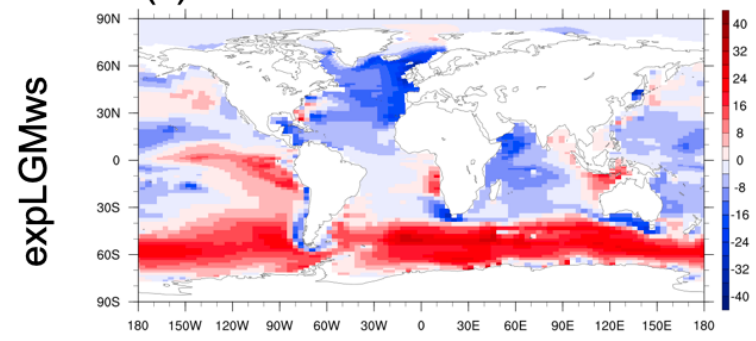

(d) Nitrate @ surface

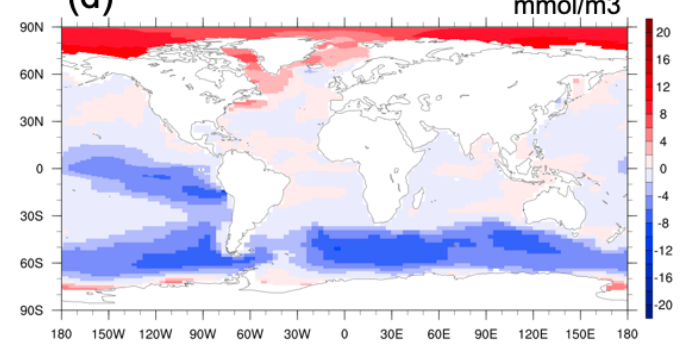

(e)

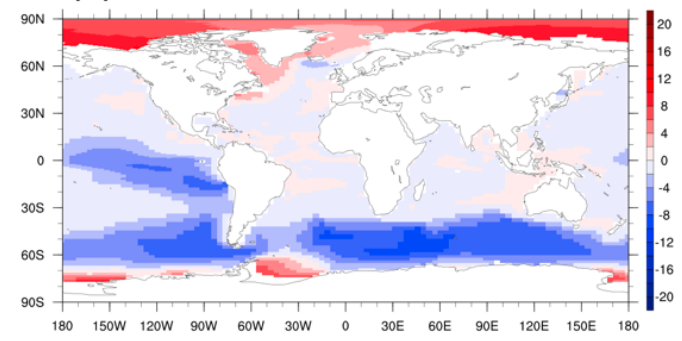

(f)

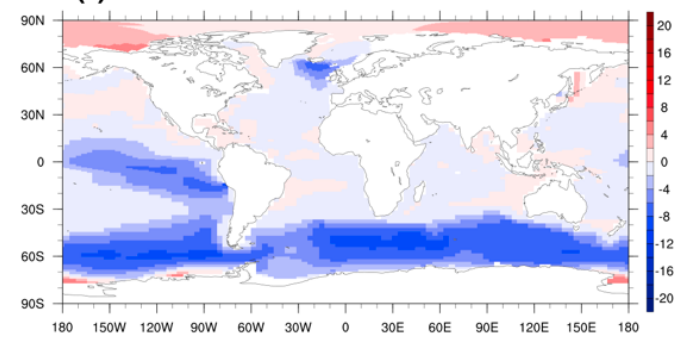

Figure 5. Carbon export at a depth of $100 \mathrm{~m}$ (left panels) and the concentration of nitrate at the surface (right panels). The differences from those in expPI are shown for each of the LGM runs: expLGM (a,d), expLGMss (b,e), and expLGMws (c, f). The average states in the last 50 years are shown. 
https://doi.org/10.5194/cp-2022-8

Preprint. Discussion started: 14 February 2022

(c) Author(s) 2022. CC BY 4.0 License.

(c) (i)
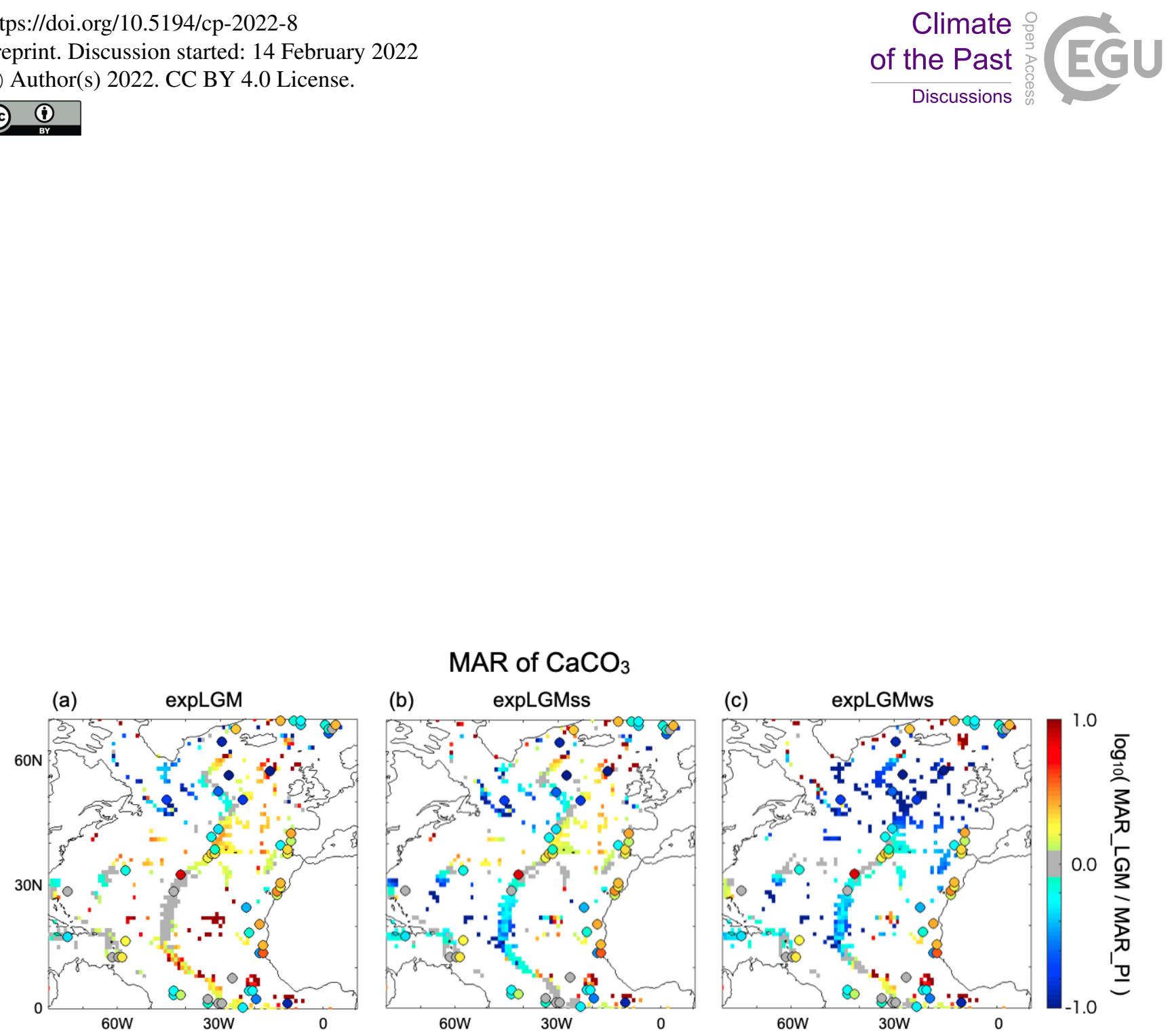

Figure 6. Mass accumulation rate (MAR) of $\mathrm{CaCO}_{3}$ in the upper sediment simulated with MEDUSA. The ratio of MAR in the respective LGM run to that in expPI run is shown on a logarithmic scale: (a) expLGM, (b) expLGMss, and (c) expLGMws. Note that the regions where the $1^{\circ} \times 1^{\circ}$ bathymetry is outside of the POP2 depth domain are excluded. The observation-based data by Cartapanis et al. (2018) are shown as overlaid dots. 
https://doi.org/10.5194/cp-2022-8

Preprint. Discussion started: 14 February 2022

(C) Author(s) 2022. CC BY 4.0 License.

(c) (i)
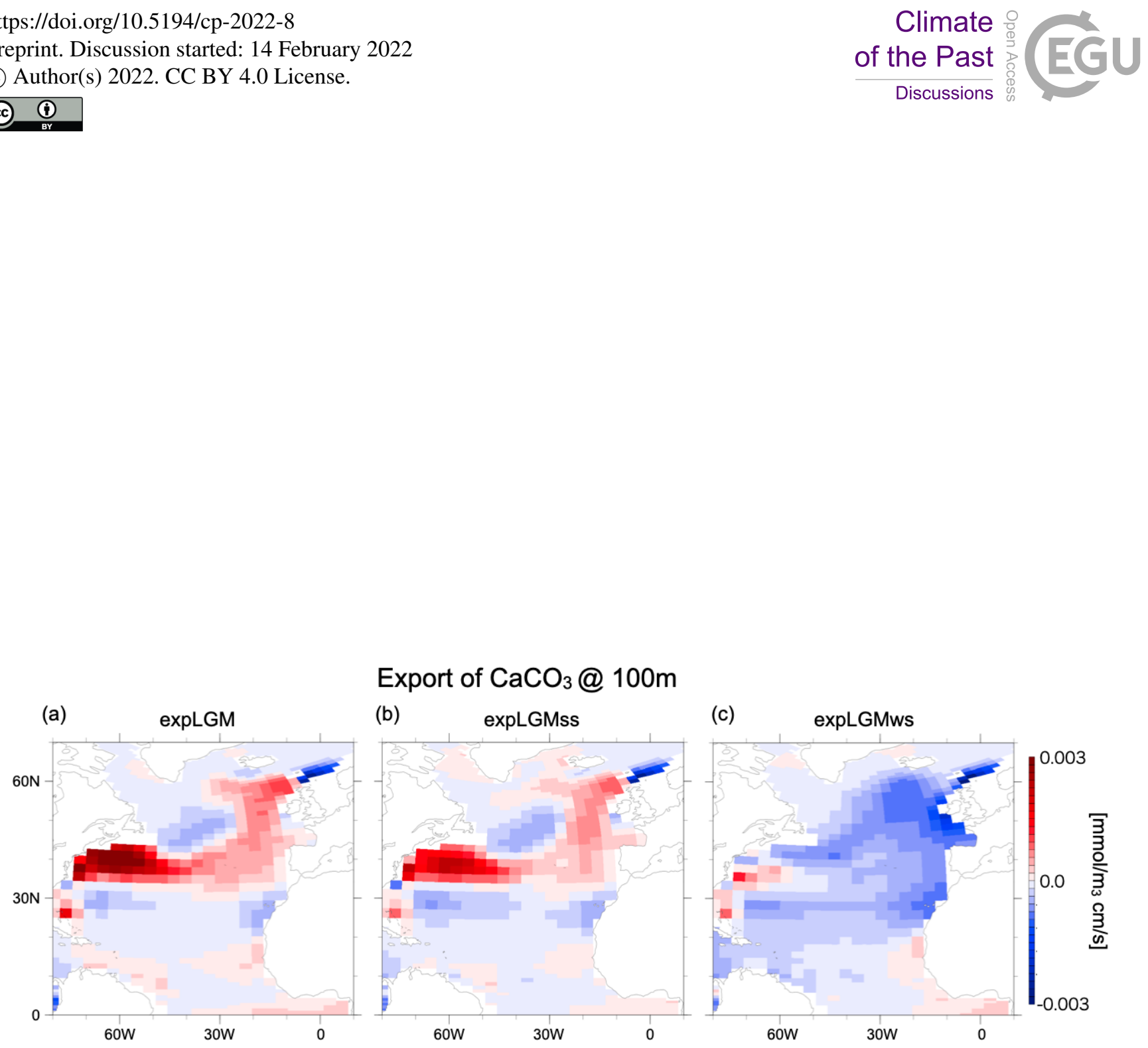

Figure 7. Simulated $\mathrm{CaCO}_{3}$ export at the depth of $100 \mathrm{~m}$. The differences between each of the LGM runs and expPI run are shown: (a) expLGM, (b) expLGMss, and (c) expLGMws. 
https://doi.org/10.5194/cp-2022-8

Preprint. Discussion started: 14 February 2022

(c) Author(s) 2022. CC BY 4.0 License.

(c) (i)
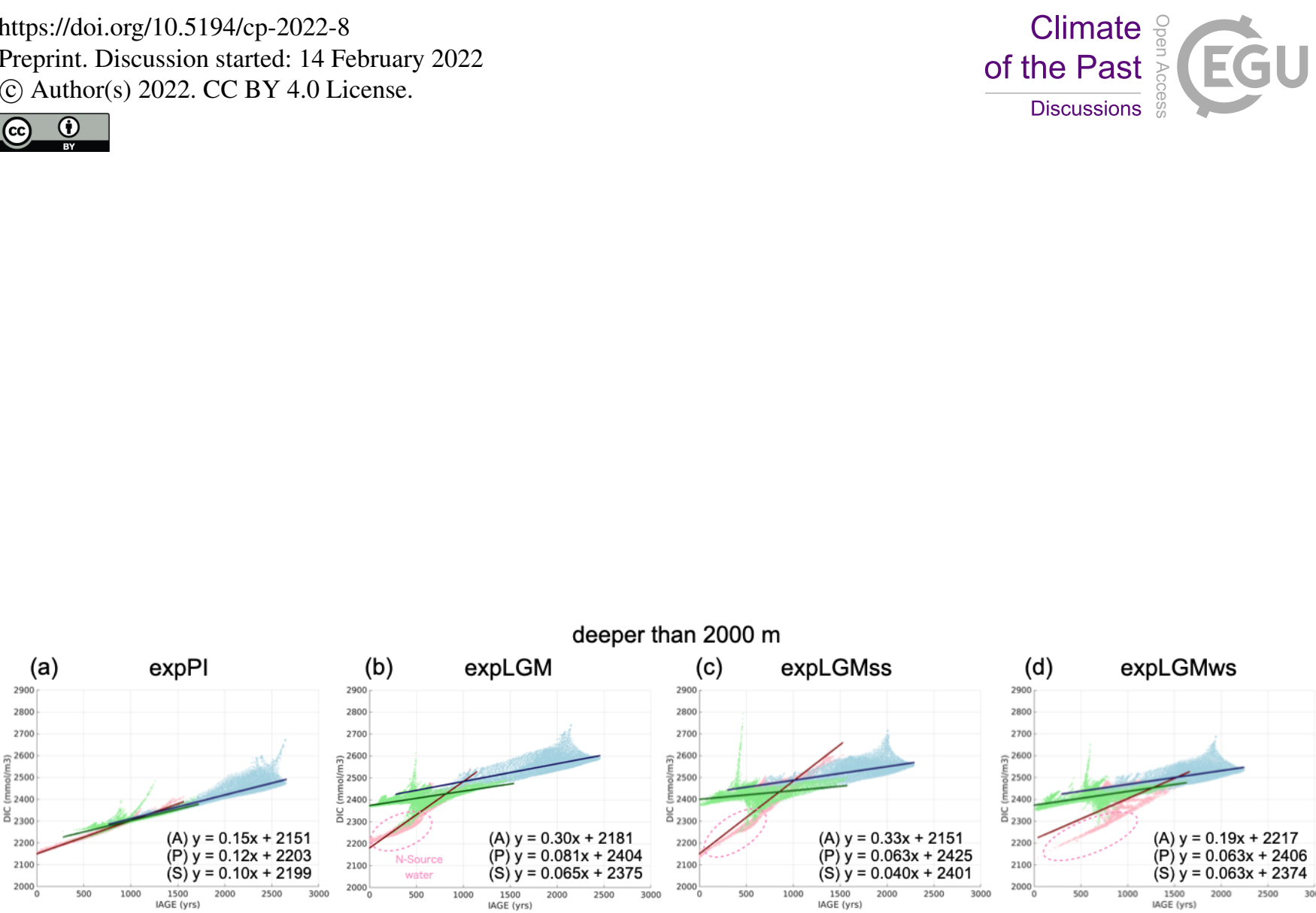

(c) expLGMss

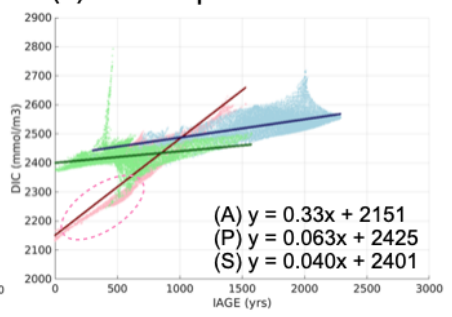

(d) expLGMws

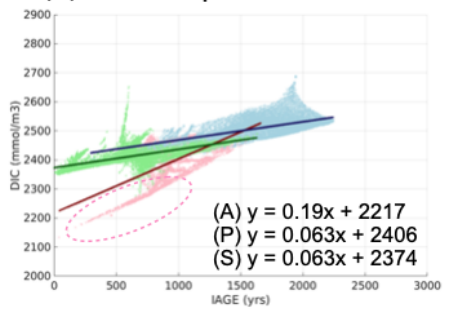

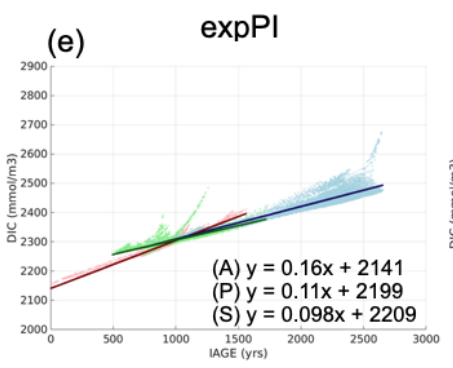
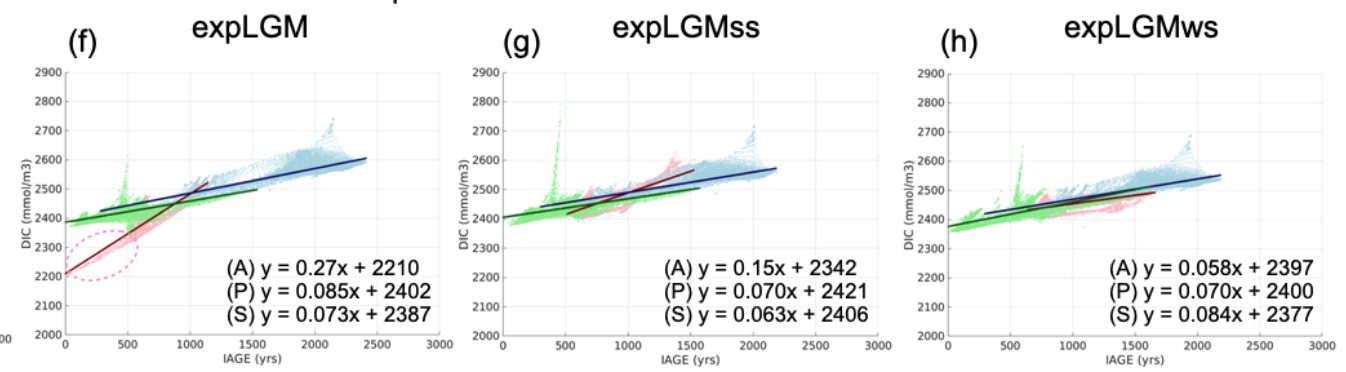

Figure 8. Scatter plots showing the correlations between DIC concentrations and the ideal age of local water for the Atlantic (red), the Pacific (blue), and the Southern Ocean (green). The linear-regression coefficients are also shown at the lower-right of each panel, where $x$ denotes the ideal age (years) and $y$ the concentration of DIC $\left(\mathrm{mmol} / \mathrm{m}^{3}\right)$. The upper four panels show the properties of water that is deeper than 2000 $\mathrm{m}$, and the lower for deeper than $3000 \mathrm{~m}$. 